\title{
A Partial Chromosomal Deletion Caused by Random Plasmid Integration Resulted in a Reduced Virulence Phenotype in Fusarium graminearum
}

\author{
Thomas K. Baldwin, ${ }^{1}$ Iffa Gaffoor, ${ }^{2}$ John Antoniw, ${ }^{1}$ Corrie Andries, ${ }^{2}$ John Guenther, ${ }^{2}$ Martin Urban, ${ }^{1}$ \\ Heather E. Hallen-Adams, ${ }^{2}$ John Pitkin, ${ }^{3}$ Kim E. Hammond-Kosack, ${ }^{1}$ and Frances Trail ${ }^{2}$ \\ ${ }^{1}$ Department of Plant Pathology and Microbiology, Rothamsted Research, Harpenden, Herts, AL5 2JQ, U.K.; ${ }^{2}$ Departments \\ of Plant Biology and Plant Pathology, Michigan State University, East Lansing, MI 48824, U.S.A.; ${ }^{3}$ Monsanto Co., \\ 700 Chesterfield Pkwy W, Chesterfield, MO 63017-1732, U.S.A.
}

Submitted 18 November 2009. Accepted 29 March 2010.

Fusarium graminearum (teleomorph: Gibberella zeae) is an Ascomycete fungal plant pathogen which infects a range of agriculturally important crops, including wheat, barley, and maize. A random plasmid insertion mutagenesis approach was used to analyze the pathogenicity of the PH-1 strain, for which full genomic information is available. Fungal transformants were initially screened for their ability to infect wheat ears. From a total of 1,170 transformants screened, eight were confirmed to be highly reduced in pathogenicity toward wheat ears and roots. These were designated disease-attenuated $F$. graminearum (daf) mutants. The in vitro growth rate and appearance of each $d a f$ mutant was equivalent to the parental strain. Deoxynivalenol (DON) was not detected in threshed grain recovered from ears inoculated with the daf10 mutant. Plasmid rescue and sequencing of the mutant daf10 revealed a deletion of approximately $350 \mathrm{~kb}$ from one end of chromosome 1. This chromosome segment is predicted to contain 146 genes. Microarray analysis of daf10 gene expression during growth in DON-inducing conditions confirmed the large deletion. The identities of the genes deleted and their potential role in DON production, pathogenesis, and other life processes are discussed.

Fusarium ear blight (FEB) disease of cereal crops causes considerable losses in grain quality and safety throughout the world (Parry et al. 1995; Beacham et al. 2009; Trail 2009). The two main pathogens which cause FEB on wheat are the fungi

Thomas K. Baldwin and Iffa Gaffoor contributed equally to this article. Kim Hammond-Kosack and Frances Trail contributed equally to this article.

Current address of T. K. Baldwin: INRA-Rennes, UMR BiO3P, 35653 Le Rheu cedex, France.

Corresponding authors: Frances Trail; Telephone +1.517.432.2939; Fax +1.517.353.1926; E-mail trail@msu.edu; or Kim Hammond-Kosack; Telephone +44 (0)1582 763133; ext 2240, Fax +44 (0)1582 715009; E-mail: Kim.Hammond-Kosack@bbsrc.ac.uk

Microarray data and cell intensity files are available at Plexdb (the Plant Expression database) under accession number FG17.

* The $\boldsymbol{e}$-Xtra logo stands for "electronic extra" and indicates that four supplementary figures and three supplementary tables are published online.
Fusarium graminearum Schwabe, sexual stage Gibberella zeae (Schwein.) Petch, and F. culmorum (W. G. Sm.) Sacc.

$F$. graminearum and F. culmorum produce a range of B-type trichothecene compounds, including nivalenol (NIV), deoxynivalenol (DON, also known as vomitoxin), and the acetylated derivatives 3-acetyl-DON and 15-acetyl-DON. These are sesquiterpenoid toxins produced as secondary metabolites which accumulate in the infected grain of wheat (Kimura et al. 2007). Consumption of trichothecene compounds can cause health problems in animals, poultry, and humans. In addition, FEB is associated with a reduction in the baking and brewing qualities of infected grain. Legislation now limits DON concentrations in finished grain products for human consumption to $1 \mathrm{ppm}$ in the United States and $0.5 \mathrm{ppm}$ in the European Union (European Commission Regulation no. 856/2005).

In $F$. graminearum and the related Fusarium sp., F. sporotrichioides, the biosynthetic pathway for trichothecene mycotoxins has been intensively investigated. The genes for DON biosynthesis reside primarily in a $25-\mathrm{kb}$ cluster, a second, smaller two-gene cluster, and at least one gene, TRI101, residing elsewhere (Kimura et al. 2007). The major cluster includes TRI5, encoding trichodiene synthase, which is responsible for generation of trichodiene from farnesyl pyrophosphate, and structural genes TRI3-TRII4. TRII, a regulatory gene, and TRII6 reside elsewhere in the genome. TRI4, TRI101, TRI11, and TRI3 catalyze the synthesis of calonectrin, which can then be used to synthesize nivalenol, 3-acetyl-DON, 15-acetyl-DON, or DON, in $F$. graminearum, or as a precursor to T-2 toxin in other fungi. Biosynthesis of 15 -acetyl-DON and DON requires the presence of the TRI8 and TRII genes for completion of the pathway. TRI6 and TRIIO are regulatory genes (Seong et al. 2009). The generation of $F$. graminearum mutants unable to produce DON, by targeted gene deletion, has revealed the importance of this mycotoxin during the infection of wheat ears (Proctor et al. 1995; Jansen et al. 2005; Cuzick et al. 2008). In addition, three different mitogen-activated protein kinase signaling cascades have been demonstrated to contribute to the genetic control of DON trichothecene production (Hou et al. 2002; Urban et al. 2003; Ramamoorthy et al. 2007; Ochiai et al. 2007).

In this study, we describe the use of random insertional mutagenesis to generate a library of hygromycin-resistant $\left(\mathrm{Hyg}^{\mathrm{r}}\right)$ F. graminearum transformants. More than 1,000 transformants were screened on wheat ears and eight reduced-viru- 
lence mutants were identified. The pathogenic effects on wheat ear development, mycotoxin production in grain, and root growth have been characterized, along with several in vitro growth and development phenotypes. The precise location of the plasmid integration in the genome of one of these mutants was elucidated using plasmid rescue, sequencing, microarray analysis, and infection of Arabidopsis floral tissue. Our data demonstrated that a large block of genes at the end of chromosome 1 are dispensable for many life processes but that this region contains genes conferring full virulence on wheat.

\section{RESULTS}

Generation of a library of $\boldsymbol{F}$. graminearum transformants and screening on wheat ears.

A library of 5,000 transformants was generated by random plasmid insertion using two different plasmids to create the transformant population. The plasmid pHA1.3 was originally created as an autonomously replicating plasmid for $F$. oxysporum research and subsequently used for high-efficiency transformation of Colletotrichum lindemuthianum (Redman
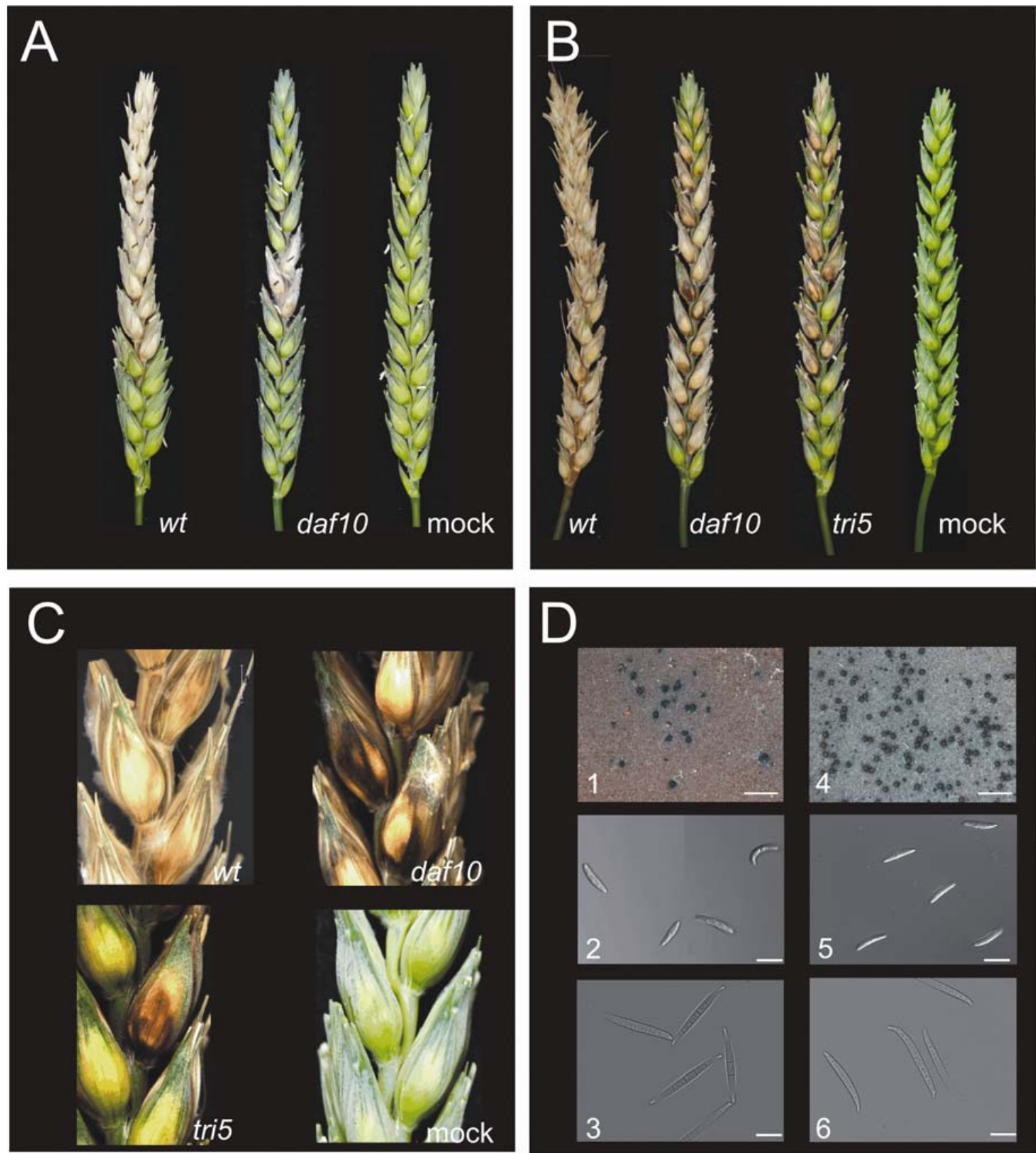

Fig. 1. Comparison of in planta and in vitro phenotypes of the wild-type strain, the daflo mutant, and the deoxynivalenol mycotoxin nonproducing tri5 mutant of Fusarium graminearum. A, Wheat ears of the susceptible cv. Bobwhite 10 days after point inoculation of two spikelets with either a water droplet containing 200 macroconidiospores or water only. The black pen marks indicate the inoculated spikelets. B, Wheat ears 10 days after spray inoculation with a conidial suspension $\left(5 \times 10^{4} \mathrm{ml}^{-1}\right)$. Both the daflo and the nontrichothecene-producing tri5 mutant (also generated in the PH-1 background) produce characteristic eye-shaped lesions on the outer glumes. However, daf10 causes more severe bleaching of the wheat ear than tri5. The ears inoculated with wildtype strain PH-1 have completely bleached. C, Close-up of the spray-inoculated spikelets reveals that, although the daf10 infections result in less symptom development than the wild-type strain PH-1, the daf10 infections cause tissue browning in the rachis and more severe necrosis on the outer glumes, and develop considerably more aerial mycelium compared with the tri5 mutant. D, In vitro comparison of daf10 (left column) and wild-type strain PH-1 (right column); 1 and 4, perithecial development on carrot agar; 2 and 5, ascospores; and 3 and 6, macroconidiospores. Bars $=2 \mathrm{~mm}$ in 1 and 4 and $20 \mu \mathrm{m}$ in 2,3 , 5 , and 6 . 
and Rodriguez 1994). This plasmid contains approximately 140 bp of $F$. oxysporum telomeric DNA. The second plasmid, pUCH2-8, contained the hygromycin phosphotransferase $(H P H)$ gene fused to promoter 1 from Cochliobolus heterostrophus and no telomeric DNA (Turgeon et al. 1987).

A population of $\mathrm{Hyg}^{\mathrm{r}}$ transformants was selected at random from this library for plant infection assays. In total, 1,170

Table 1. Mean number of wheat spikelets with visible disease symptoms 20 days postinoculation

\begin{tabular}{lc}
\hline Treatment & Diseased spikelets $^{\mathbf{z}}$ \\
\hline Uninoculated & 0 \\
Synthetic nutrient-poor agar control & 0 \\
PH-1 wild-type & $15.33( \pm 1.21)$ \\
daf 10 & $2.17( \pm 0.26)$ \\
daf 14 & $5.01( \pm 1.67)$ \\
daf 15 & $2.33( \pm 0.82)$ \\
daf 26 & $1.75( \pm 0.42)$ \\
daf 36 & $2.17( \pm 0.41)$ \\
daf 37 & $3.75( \pm 2.60)$ \\
daf 38 & $1.83( \pm 0.41)$ \\
daf 43 & $4.17( \pm 3.96)$ \\
\hline
\end{tabular}

${ }^{\mathrm{z}}$ Values are means \pm 1 standard deviation. transformants were tested, of which 847 transformants were generated with plasmid pHA1.3 and 323 transformants were generated with plasmid pUCH2.8. Eight transformants were confirmed to be highly reduced in their ability to cause disease symptoms on wheat ears and were named disease-attenuated $F$. graminearum (daf) mutants. The daf mutants 10, 14, 15, 26, 37 , and 38 were generated by pHA1.3, and daf 26 and daf43 were generated by pUCH2.8. The full infection phenotype of each daf mutant was explored in detail by inoculating six flowering wheat ears, of the susceptible cv. Bobwhite, by the point inoculation technique (Table 1). In these infection tests, hyphae of the wild-type parent $\mathrm{PH}-1$ colonized the entire wheat ear within 20 days and caused every spikelet to bleach and the awns to assume a horizontal posture. None of the eight mutants caused visible symptoms on more than half of the entire ear by day 20 postinoculation. After this time, no further visible disease progression occurred (Table 1; Fig. 1). Forty days after inoculation, each ear was harvested and divided into three regions-i) above the point of inoculation, ii) with visible disease symptoms, and iii) below the point of inoculation and without symptoms - and then hand threshed. This revealed the grain number and type recoverable from each region (Tables 2 and 3). This detailed analysis revealed the dramatic effect the

Table 2. Impact of Fusarium graminearum infection on grain weight and number in the ear

\begin{tabular}{|c|c|c|c|c|c|c|c|}
\hline \multirow[b]{3}{*}{ Treatment } & \multirow{2}{*}{\multicolumn{3}{|c|}{ Entire ear ${ }^{w}$}} & \multicolumn{4}{|c|}{ Per spikelet $^{\mathrm{w}, \mathrm{x}}$} \\
\hline & & & & \multicolumn{2}{|c|}{ Region B } & \multicolumn{2}{|c|}{ Region C } \\
\hline & Wt (mg) & No. & Spikelets $^{\mathbf{y}}$ & Wt (mg) & No. & Wt (mg) & No. \\
\hline None & $2,255 \mathrm{c}$ & $41.3 \mathrm{~b}$ & 0 & $80 \mathrm{c}$ & $2.1 \mathrm{c}$ & $144 \mathrm{c}$ & $2.69 \mathrm{c}$ \\
\hline SNA only ${ }^{z}$ & $1,718 \mathrm{bc}$ & $37.5 \mathrm{~b}$ & 0 & $67.5 \mathrm{bc}$ & $1.79 \mathrm{bc}$ & $109.38 \mathrm{bc}$ & $2.45 \mathrm{c}$ \\
\hline PH-1 & 219 a & $0.5 \mathrm{a}$ & 15.33 & $0 \mathrm{a}$ & $0 \mathrm{a}$ & $109.5 \mathrm{bc}$ & $1.3 \mathrm{~b}$ \\
\hline \multicolumn{8}{|l|}{ daf mutant } \\
\hline 10 & $1,561 \mathrm{bc}$ & $33.5 \mathrm{~b}$ & 2.17 & $6.45 \mathrm{a}$ & $0.46 \mathrm{ab}$ & $92.36 \mathrm{~b}$ & $2.32 \mathrm{c}$ \\
\hline 14 & $1,463 \mathrm{~b}$ & $21.5 \mathrm{ab}$ & 5.00 & $27 \mathrm{ab}$ & $1.3 \mathrm{abc}$ & $123 \mathrm{bc}$ & $2.13 b c$ \\
\hline 15 & $1,596 \mathrm{~b}$ & $15.7 \mathrm{ab}$ & 2.33 & $5.15 \mathrm{a}$ & $0.47 \mathrm{ab}$ & $112 \mathrm{bc}$ & $1.74 \mathrm{ba}$ \\
\hline 26 & $1,465 \mathrm{~b}$ & $22.5 \mathrm{ab}$ & 1.75 & $2.86 \mathrm{a}$ & $0.28 \mathrm{a}$ & $96.08 \mathrm{bc}$ & $1.84 \mathrm{bc}$ \\
\hline 36 & $936 \mathrm{ab}$ & $17.3 \mathrm{ab}$ & 2.17 & $0 \mathrm{a}$ & $0.32 \mathrm{ab}$ & $71.55 \mathrm{~b}$ & $2.31 \mathrm{c}$ \\
\hline 37 & $873 \mathrm{ab}$ & $23 \mathrm{ab}$ & 3.75 & $11.57 \mathrm{ab}$ & $0.85 \mathrm{ab}$ & $69.51 \mathrm{~b}$ & $2.4 \mathrm{c}$ \\
\hline 38 & $1,277 \mathrm{ab}$ & $30.2 \mathrm{~b}$ & 1.83 & $2.19 \mathrm{a}$ & $0.44 \mathrm{ab}$ & $86.26 \mathrm{~b}$ & $2.41 \mathrm{c}$ \\
\hline 43 & $1,506 \mathrm{~b}$ & $34.5 \mathrm{~b}$ & 4.17 & $24.7 \mathrm{ab}$ & $1.39 \mathrm{abc}$ & $95.44 \mathrm{bc}$ & $2.75 \mathrm{c}$ \\
\hline $\mathrm{S}^{2}$ at $5 \%$ & 1,196 & 27.53 & $\ldots$ & 60 & 1.48 & 51.46 & 0.94 \\
\hline
\end{tabular}

${ }^{\mathrm{w}} \mathrm{Wt}=$ grain weight and No. = grain number; values in each column which differ by the letters indicated are statistically significant from each other at the $5 \%$ level.

${ }^{\mathrm{x}}$ Ear region $\mathrm{B}$, visible disease symptoms and ear region $\mathrm{C}$, no macroscopically visible disease symptoms.

y Number of visible disease spikelets.

${ }^{\mathrm{z}} \mathrm{SNA}=$ synthetic nutrient-poor agar.

Table 3. Impact of Fusarium graminearum infection on grain weight, number, and quality in the entire ear and the three different ear subregions (A, B, and C) ${ }^{\mathrm{x}}$

\begin{tabular}{|c|c|c|c|c|c|c|c|c|c|c|c|c|c|c|c|}
\hline \multirow[b]{3}{*}{ Treatment } & \multicolumn{5}{|c|}{ Region A } & \multicolumn{5}{|c|}{ Region B } & \multicolumn{5}{|c|}{ Region C } \\
\hline & \multirow[b]{2}{*}{ Wt (mg) } & \multirow[b]{2}{*}{ No. } & \multicolumn{3}{|c|}{ Quality $^{\mathbf{y}}$} & \multirow[b]{2}{*}{ Wt (mg) } & \multirow[b]{2}{*}{ No. } & \multicolumn{3}{|c|}{ Quality $^{\mathbf{y}}$} & \multirow[b]{2}{*}{ Wt (mg) } & \multirow[b]{2}{*}{ No. } & \multicolumn{3}{|c|}{ Quality $^{\mathbf{y}}$} \\
\hline & & & $\mathbf{L}$ & M & $\mathbf{S}$ & & & $\mathbf{L}$ & $\mathbf{M}$ & $\mathbf{S}$ & & & $\mathbf{L}$ & $\mathbf{M}$ & $\mathbf{S}$ \\
\hline None & $243 \mathrm{~b}$ & $5.8 \mathrm{abc}$ & 86 & 14 & 0 & $160 \mathrm{a}$ & 4.2 & 100 & 0 & 0 & $1,872 \mathrm{~b}$ & 31.3 & 98 & 1 & 1 \\
\hline SNA only ${ }^{z}$ & $161 \mathrm{~b}$ & $4.5 \mathrm{abc}$ & 89 & 4 & 7 & $135 \mathrm{a}$ & 3.5 & 90 & 0 & 10 & $1,422 \mathrm{~b}$ & 29.5 & 98 & 0 & 2 \\
\hline $\begin{array}{l}\text { PH-1 } \\
\text { daf mutant }\end{array}$ & $0 \mathrm{a}$ & $0.4 \mathrm{a}$ & 0 & 0 & 100 & $0 \mathrm{a}$ & 0 & NS & NS & NS & $219 \mathrm{a}$ & 2.6 & 0 & 0 & 100 \\
\hline 10 & $362 \mathrm{~b}$ & $10.8 \mathrm{bc}$ & 88 & 3 & 9 & $14 \mathrm{a}$ & 1 & 0 & 0 & 100 & $1,185 \mathrm{ab}$ & 30.6 & 81 & 9 & 10 \\
\hline 14 & $98 \mathrm{a}$ & $5.3 \mathrm{abc}$ & 53 & 19 & 28 & $135 \mathrm{a}$ & 6.5 & 5 & 18 & 77 & $1,230 \mathrm{ab}$ & 22 & 53 & 43 & 4 \\
\hline 15 & $165 \mathrm{ab}$ & $3.5 \mathrm{ab}$ & 62 & 38 & 0 & $0 \mathrm{a}$ & 1.1 & 0 & 33 & 66 & $1,419 \mathrm{~b}$ & 22.6 & 52 & 36 & 12 \\
\hline 26 & $187 \mathrm{ab}$ & $5.5 \mathrm{abc}$ & 82 & 9 & 9 & $5 \mathrm{a}$ & 0.5 & 0 & 0 & 100 & $1,273 \mathrm{ab}$ & 25 & 66 & 24 & 10 \\
\hline 36 & $18 \mathrm{a}$ & $4.5 \mathrm{abc}$ & 59 & 26 & 15 & $0 \mathrm{a}$ & 0.7 & 0 & 0 & 100 & $918 \mathrm{ab}$ & 30.5 & 42 & 18 & 40 \\
\hline 37 & $48 \mathrm{a}$ & $4.3 \mathrm{abc}$ & 62 & 8 & 30 & $43 \mathrm{a}$ & 3.2 & 0 & 0 & 100 & $782 \mathrm{ab}$ & 27.9 & 55 & 13 & 32 \\
\hline 38 & $13 \mathrm{ab}$ & $4.7 \mathrm{bc}$ & 50 & 36 & 14 & $4 \mathrm{a}$ & 0.8 & 0 & 0 & 100 & $1,136 \mathrm{ab}$ & 32.6 & 75 & 9 & 16 \\
\hline 43 & $74 \mathrm{~b}$ & $7.3 \mathrm{bc}$ & 75 & 2 & 23 & $103 \mathrm{a}$ & 5.8 & 0 & 23 & 77 & $1,129 \mathrm{ab}$ & 30.6 & 70 & 9 & 21 \\
\hline
\end{tabular}

${ }^{\mathrm{x}}$ Ear region A (constant size), above the point of plug inoculation; ear region $\mathrm{B}$ (variable size), visible disease symptoms; and ear region $\mathrm{C}$ (variable size), no macroscopically visible disease symptoms or no infection. $\mathrm{Wt}=$ mean grain weight per region per ear and No. $=$ mean grain number per region per ear; values in each column which differ by the letters indicated are statistically significant from each other at the $5 \%$ level.

${ }^{\mathrm{y}}$ Grain quality: $\mathrm{L}=$ large, $\mathrm{M}=$ medium, and $\mathrm{S}=$ small grain, expressed as a percentage of each category; NS = no seed.

${ }^{\mathrm{z}} \mathrm{SNA}=$ synthetic nutrient-poor agar. 
wild-type PH-1 strain had on grain development, whereas most of the daf mutant infections permitted more and larger grains to develop within both the symptom and symptomless regions of the ear.

Ability of Fusarium mutants to invade root and stem tissues.

A previously established seed germination assay in the presence or absence of $F$. graminearum inoculum (Urban et al. 2003) was used to examine the ability of each daf mutant to attack the root and stem base tissue of young seedlings. In the field, this type of infection often arises from Fusarium spp.infected crop residues or from the sowing of infected seed, to cause a seedling blight disease that lowers the initial crop density (Parry et al. 1995).

PH-1 severely impaired seedling emergence to between 14 and $23 \%$ of that recovered from the mock-inoculated water controls (Table 4). In the first experimental replicate, aerial seedling biomass 21 days after inoculation was also significantly reduced following $\mathrm{PH}-1$ infection. The eight daf mutants with a reduced ability to invade wheat ears at flowering permitted both good seedling emergence and seedling growth in both experimental replicates (Table 4). In experiment 2, where considerably higher levels of disease occurred, three daf mutants caused a greater impact on seedling emergence; however, this effect was still considerably less than PH-1.

When the wheat roots were washed free of vermiculite, clear differences between the root systems were visible. Infections by $\mathrm{PH}-1$ caused extreme stunting of the root system, with only two to three short main roots and no lateral roots or root hairs, and roots were a light brown color (data not shown). In contrast, the roots recovered from the mutant-inoculated plants were all large, with many primary, secondary, and tertiary roots, and appeared very similar to those of the mock-inoculated plants. Microscopic examination of trypan blue-stained roots revealed that hyphae of $\mathrm{PH}-1$ had infected the roots and colonized the various tissue layers both intercellularly and intracellularly. In contrast, microscopic observations of roots inoculated with each daf mutant failed to identify the presence of fungal mycelium inside root tissue (data not shown). It is possible that small peripheral root infections formed by a mutant were removed when the vermiculite was washed away from the roots and, thereby, lost from the subsequent analyses.

In vitro growth and sexual and asexual spore production.

The in vitro hyphal growth rates were compared on synthetic nutrient-poor agar (SNA) and Vogel's minimal medium agar (VM) for 5 days. No statistically significant differences

Table 4. Effect of inoculations with daf mutants on wheat seed germination and seedling aerial biomass

\begin{tabular}{|c|c|c|c|c|}
\hline \multirow[b]{2}{*}{ Treatment } & \multicolumn{2}{|c|}{ Seed germination $(\%)$} & \multicolumn{2}{|c|}{$\begin{array}{l}\text { Aerial biomass (g) per } \\
\text { germinated seedling }\end{array}$} \\
\hline & Exp. 1 & Exp. $2^{y}$ & Exp. 1 & Exp. 2 \\
\hline None & 100 & 95 & 0.24 & 0.33 \\
\hline $\mathrm{SNA}^{\mathrm{z}}$ & 95 & 100 & 0.20 & 0.23 \\
\hline PH-1 & 24 & 14 & 0.10 & 0.20 \\
\hline daf 10 & 90 & $57 * *$ & 0.15 & 0.17 \\
\hline daf 14 & 62 & 76 & 0.18 & 0.22 \\
\hline daf 15 & 80 & $38 * *$ & 0.21 & 0.30 \\
\hline daf 26 & 90 & 76 & 0.26 & 0.28 \\
\hline daf 36 & 80 & 67 & 0.19 & 0.19 \\
\hline daf 37 & 67 & 52 & 0.22 & 0.31 \\
\hline daf 38 & 90 & 86 & 0.30 & 0.25 \\
\hline daf 43 & 90 & $33 * *$ & 0.21 & 0.35 \\
\hline Standard deviation & 21 & 28.5 & 0.05 & 0.08 \\
\hline
\end{tabular}

${ }^{\mathrm{y}}$ In experiment 2 , the overall effect of the disease was higher; $* *$ indicates significantly lower seed germination in experiment 2 .

${ }^{\mathrm{z}} \mathrm{SNA}=$ synthetic nutrient-poor agar. were evident in the daily rate of hyphal extension on either growth media. For each daf mutant, the onset of asexual conidiation, the overall abundance of conidia formed, and the size of conidia on both SNA and VM plates were comparable with that observed for PH-1 (Fig. 1).

Perithecial formation was assessed by growing each daf mutant on carrot agar. Seven of the eight daf mutants produced normal-size perithecia containing abundant ascospores in an identical manner to PH-1. For daf38, perithecia developed after an additional 5 days in culture compared with other mutants and the PH-1 wild-type control (data not shown).

DON and 15-acetyl DON mycotoxin production.

In planta, 15-acetyl DON and DON production was measured by competitive enzyme-linked immunosorbent assay (ELISA) in the hand-threshed grain recovered from each inoculated ear. PH-1 produced DON in all grain samples examined within the range 200 to $405 \mu \mathrm{g} / \mathrm{g}$ dry weight of seed $(n=9)$. The daf10 mutant produced no detectable DON levels $(<0.5$ $\mu \mathrm{g} / \mathrm{g}$ dry weight of seed). The daf15, daf26, and daf38 mutants produced low levels of DON in grain, ranging between 5 and $30 \mu \mathrm{g} / \mathrm{g}$ dry weight, whereas daf14, daf 36 , daf37, and daf43 produced wild-type levels. DON production was also investigated in vitro (Table 5) but these results did not correlate well with DON levels in the grain recovered from the inoculated wheat ear. Only daf36 and daf43 produced wild-type levels of DON in vitro as well as in wheat grain. The daflo and daf14 mutants produced low DON levels in vitro. The DON amounts detected in cultures of the daf15, daf26, daf 36 , daf38, and daf43 mutants were in the range of the wild type (Table 5).

\section{Molecular characterization of the daf10 mutant.}

Mutant daf10, for which DON was not detected by ELISA in plant material, was selected for DNA gel-blot analysis. The presence of single bands in two different diagnostic digests verified the existence of a single-plasmid insertion event (Supplementary Fig. 1).

A polymerase chain reaction (PCR) assay was designed to test the hypothesis that this no-DON in planta phenotype was due to the disruption of a TRI gene in the TRI5 gene cluster (Kimura et al. 2007). A set of primers specific for the 27-kb TRI5 gene cluster was designed to amplify the entire TRI5 locus as six overlapping, approximately 4-kb fragments (Supplementary Table 1). Electrophoresis of the PCR products revealed no size shifts in the expected sizes of any of the products amplified (Supplementary Fig. 2).

\section{Identification of flanking sequences by plasmid rescue.}

Two plasmid rescue experiments were done with DNA extracted from daf10 and digested with EcoRV. Nine EcoRV colo-

Table 5. Deoxynivalenol (DON) levels produced in vitro by the wild-type strain and the daf mutants

\begin{tabular}{lcc}
\hline & \multicolumn{2}{c}{ DON $(\mu \mathbf{g})^{\mathbf{z}}$} \\
\cline { 2 - 3 } Strain & Rep 1 & Rep 2 \\
\hline PH-1 & 284 & 71 \\
daf mutant & & \\
10 & 2.7 & 4.1 \\
14 & 2.9 & 2.6 \\
15 & 428 & 400 \\
26 & 368 & 123 \\
36 & 817 & 244 \\
37 & nd & nd \\
38 & 179 & 166 \\
43 & 203 & 351 \\
\hline
\end{tabular}

${ }^{\mathrm{z}}$ Calculated per gram (dry weight) of mycelia; nd = not determined. 


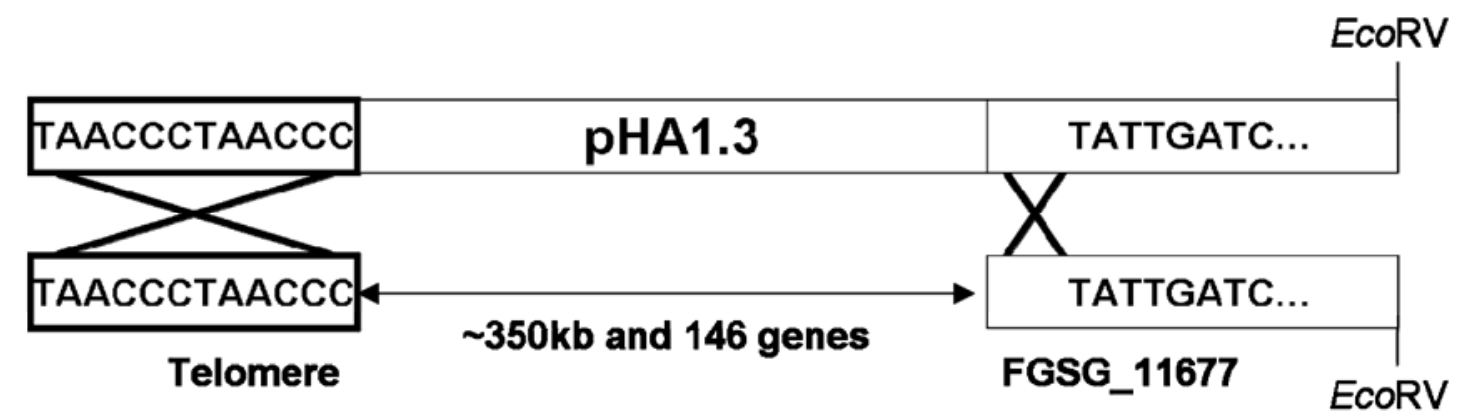

Fig. 2. Schematic of the crossover events leading to the daflo genotype.

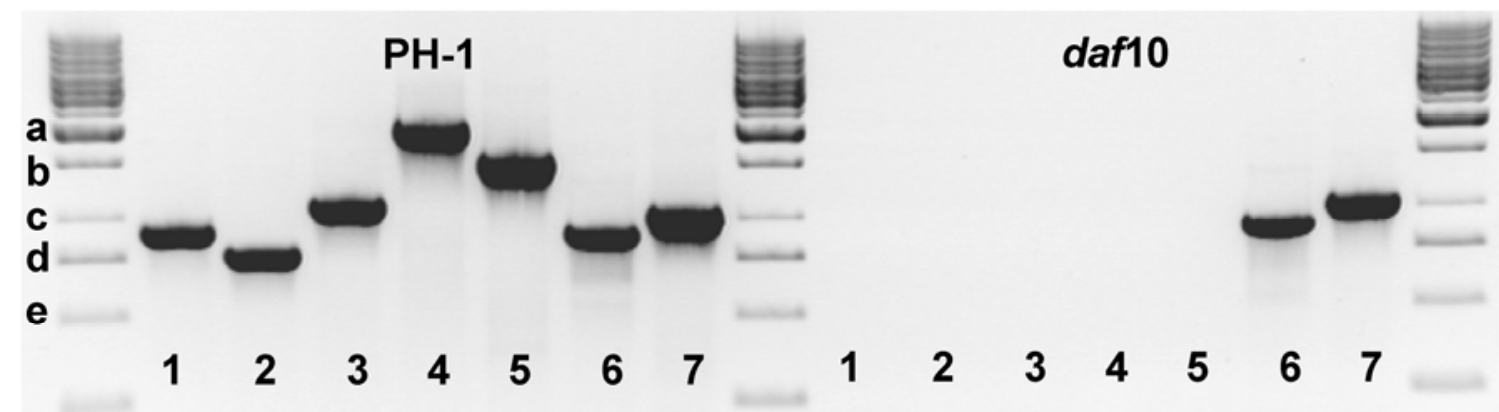

Fig. 3. Polymerase chain reaction analysis of genes predicted to have either been lost or retained on chromosome 1 in daf10. Lane 1, FGSG_11579; lane 2, FGSG_00028; lane 3, FGSG_00071 (TRII); lane 4, FGSG_00105; lane 5, FGSG_00092; lane 6, FGSG_11678; lane 7, FGSG_09897. PCR product size ladder: row a, 2,000 bp; row b, 1,500 bp; row c, 1,000 bp; row d, $750 \mathrm{bp}$; e, row $500 \mathrm{bp}$.

A WT (PH-1)

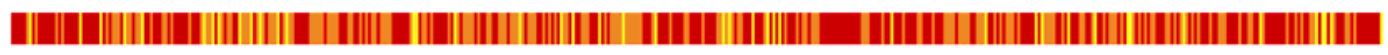

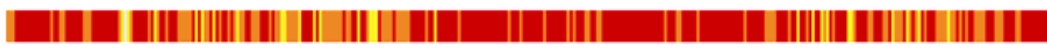

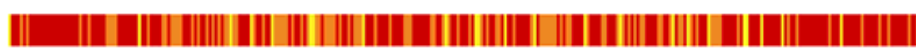

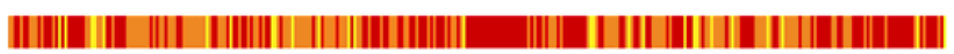

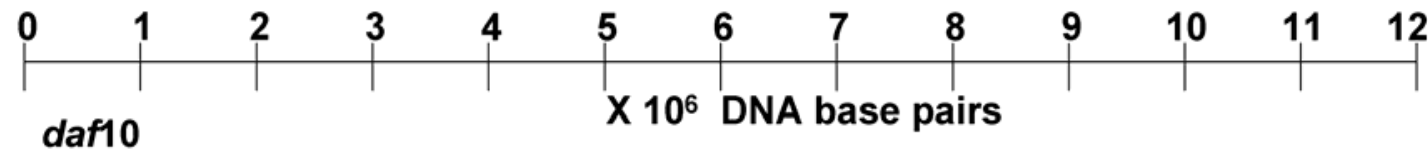

\&

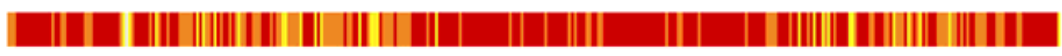

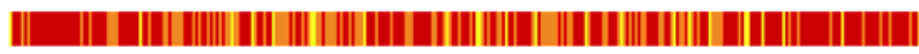

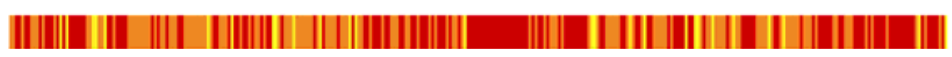

B

\section{Deleted in daf10}
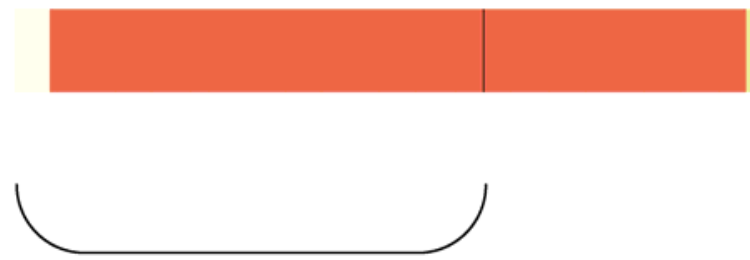

Fig. 4. Gene density and recombination rates of the wild-type (WT) PH-1 and PH-1 daf10 genomes. A, Four chromosomes of PH-1 and daf10. Gene density: yellow $=<6$ genes per $25 \mathrm{~kb}$; orange $=6$ to 9 genes per $25 \mathrm{~kb}$; red $=>9$ genes per $25 \mathrm{~kb}$. B, End of chromosome 1 showing the meiotic recombination rates $($ Gale et al. 2005) and the location of the deletion in daf10. Gray background $=<1$ centimorgans $(\mathrm{cM})$ per $27 \mathrm{~kb}$; beige $=1-2 \mathrm{cM}$ per $27 \mathrm{~kb}$; red $=4-8 \mathrm{cM}$ per $27 \mathrm{~kb}$. 
nies (pDE1-9) were picked for plasmid extraction and further analysis. When the rescued plasmids were cut with $P v u \mathrm{II}$, there was a clear shift on the gel of approximately $3.5 \mathrm{~kb}$ between the total sizes of fragments from the rescued plasmids and the original pHA1.3 plasmid (Supplementary Fig. 3), indicating that additional DNA was associated with the rescued plasmid.

\section{Sequencing of the daf 10 rescued plasmids.}

Sequencing primer AMP1 was used to sequence the cloned genomic flanks of the plasmid insertion in the pDE plasmids. Sequencing followed by BLAST analysis revealed that, in daf10, one flank of pHA1.3 was within a predicted gene locus located on chromosome 1, namely FGSG_11677. From the second flank of the plasmid, more than $130 \mathrm{bp}$ of telomeric repeat DNA [GGGTTA $]_{\mathrm{n}}$ was recovered. Further sequencing using three different primers (C1.5ANTI1, C1.5ANTI2, and C1.5ANTI3) revealed the exact nature of the plasmid insertion at the FGSG_11677 locus in daf10. The integration of pHA1.3 into the PH-1 genome to create the daflo transformant appears to have involved two crossover events. The first was a homologous recombination event between the $126 \mathrm{bp}$ of telomeric DNA in pHA1.3 and the $F$. graminearum telomere at the end

\section{F. graminearum Genome}

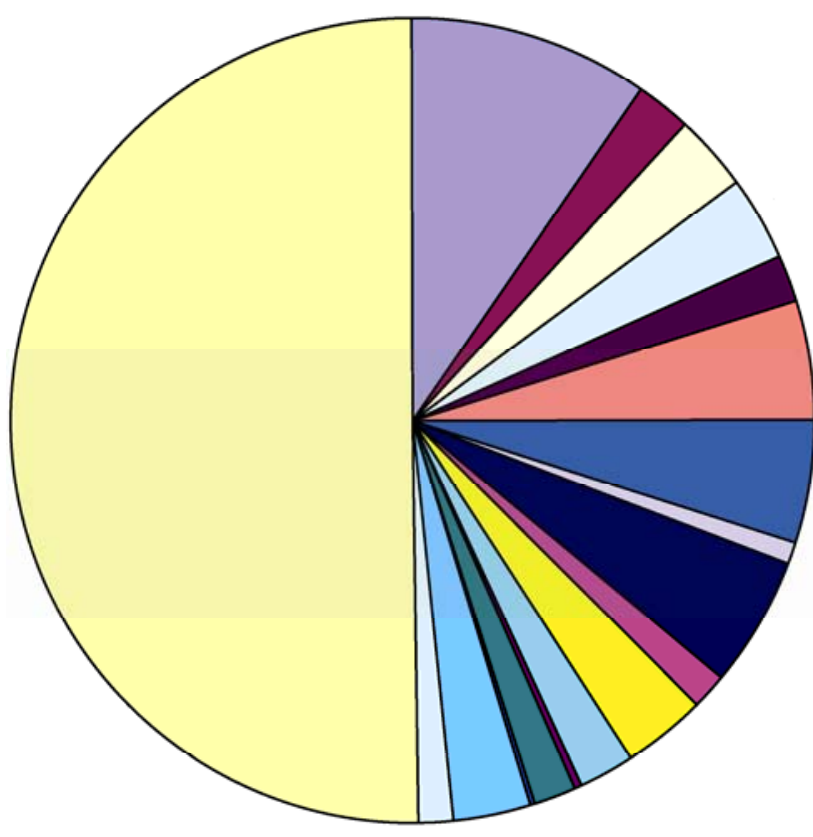

Genes lost from the daf10 mutant

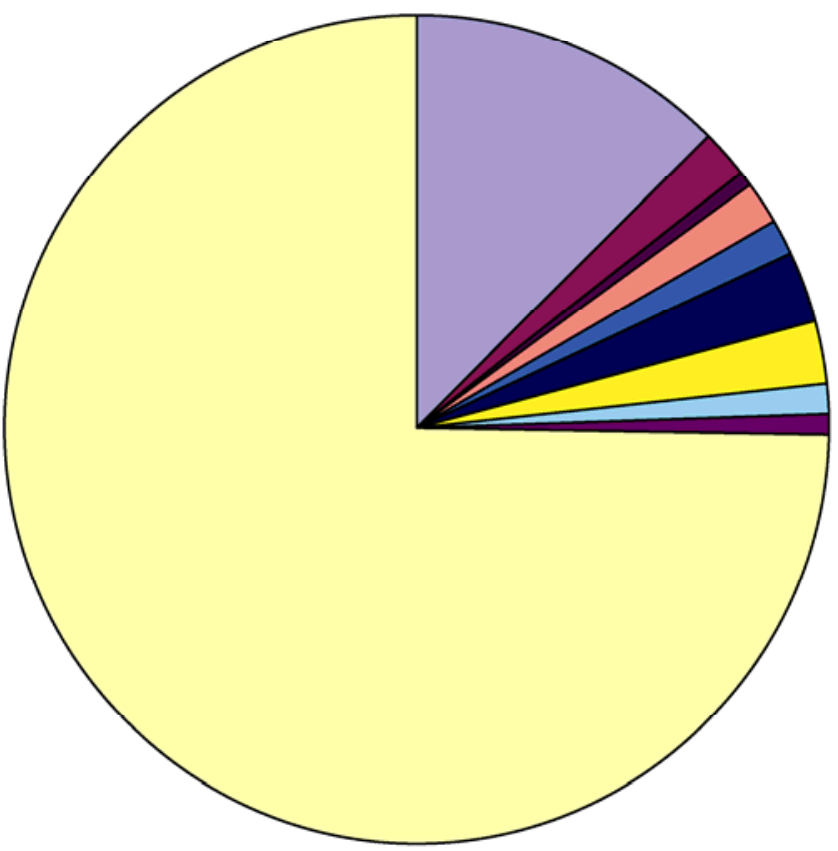

01 Metabolism

02 Energy

10 Cell Cycle and DNA Processing

11 Transcription

12 Protein Synthes is

14 Protein Fate

16 Protein with Binding Function or Cofactor Requirement

$\square 18$ Protein Activity Regulation

20 Cellular Transport

$\square 30$ Cellular Communication/Signal Transduction

32 Cell Rescue, Defense And Virulence

34 Interaction With The Cellular Environment

36 Interaction With The Environment (Systemic)

38 Transposable Elements

40 Cell Fate

41 Development (Systemic)

42 Biogenesis Of Cellular Components

43 Cell Type Differentiation 99 Unclassified Proteins

Fig. 5. MIPS functional categorization (FunCat) of the Fusarium graminearum genome and of the 146 genes lost from daf10 mutant. The lower graph shows genes lost from the daf10 mutant. 
of chromosome 1. A second recombination event occurred within the locus FGSG_11677 and did not involve any homology between the end of pHA1.3 and the DNA at the insertion site. This resulted in the deletion of the end of chromosome 1 with the pHA1.3 plasmid replacing approximately $350 \mathrm{~kb}$ of DNA and 146 predicted genes (Fig. 2).

\section{PCR evidence of gene loss.}

PCR experiments were done to test for the loss of genes predicted to be located in the genome between the plasmid insertion point in FGSG_11677 (coordinates 366,201 to 368,456) and the end of chromosome 1 . Primers were designed for five different genes across the deleted region. In addition as a positive control, primers were designed for the gene predicted to now flank the integrated plasmid (FGSG_11678) as well as for a gene located further toward the centromere of chromosome 1 (FGSG_09897). Gel electrophoresis of the PCR products confirmed that genes 1 to 5 had been lost from the genome of daf10, whereas the two positive control genes were retained (Fig. 3).

\section{Microarray analysis of daf10 gene expression.}

Further experiments were done to confirm that the 146 predicted genes had been deleted from the genome of daflo and to explore the impact of this loss on the expression of predicted genes residing elsewhere in the genome. $\mathrm{PH}-1$ and daf10 strains were grown under DON-inducing conditions for 7 days as described by McCormick and associates (2004). RNA was extracted from fungal mycelia and hybridized to the $F$. graminearum GeneChip. With one exception, none of the genes predicted to be deleted showed expression in daflo (Supplementary Tables 2 and 3). Locus FG00042.1 (Broad FG1 assembly), which was predicted to code for a nonribosomal peptide synthetase, gave a positive hybridization signal on the GeneChip. However, the expression results for the alternative gene model predicted by the Munich Information Center for Protein Sequences (MIPS) (fgd2-360) revealed that the gene at this locus was not expressed in daf10. Indeed, the most recent Broad genome assembly (FG3) has resulted in the division of locus FGSG_00042.1 into two different predicted CDS loci; namely, FGSG_11659 and FGSG_11660. Collectively, these results indicate that nonspecific binding had occurred to one or more of the probe sets originally assigned to the locus FG00042.1 in the FG1 assembly. The limits of the deletion are supported by the expression analysis. FGSG_11642 (the third annotated gene in supercontig 1, preceding FGSG_00001; coordinates 9,189 to 9,662) through to FGSG_00100 (coordinates 319,803 to 319,054 ) are within the low expression (presumed absent) block (data not shown). The first gene with significant expression is FGSG_00476, coordinates 1,472,514 to $1,473,187$.

Of the 146 genes predicted to be in the deleted region, 23 genes showed minimal expression in daflo compared with $\mathrm{PH}-1$ under DON-inducing conditions. An additional predicted coding region, with so far only expressed sequence tag (EST) support, was also downregulated. Fifteen of the deleted genes have putative annotated function and include a transcription factor (FGSG_00052). In addition, one missing gene, FGSG_00071, is known to code for the cytochrome P450 monooxygenase TRI1. In F. graminearum, TRI1 has been shown to be required for the conversion of calonectrin to 8-hydroxylcalonectrin, which is an essential step in DON mycotoxin synthesis. $F$. graminearum strains harboring a disrupted TRII gene accumulate only the 15decalonectrin and calonectrin precursors under DON-inducing conditions in vitro (McCormick et al. 2004).

These expression experiments revealed that many other genes outside the deleted region also exhibited altered gene expression under DON-inducing conditions. A total of 93 genes had increased expression in daflo compared with the wild-type strain. Of these, 31 genes (33\%) were annotated. They include two genes involved in trichothecene biosynthesis; namely, FGSG_11025, coding for the transcription factor TRI15, and FGSG_07896, coding for the trichothecene 3-Oacetyltransferase TRI101. The transcription factor TRI15 is a known negative regulator of DON mycotoxin production in $F$. sporotrichioides (Alexander et al. 2004) whereas the TRI101 gene product catalyses the transfer of an acetyl group from acetyl coenzyme A to the $\mathrm{C} 3$ hydroxyl moiety of several trichothecene mycotoxins. In vitro, this acetyl transfer modification has been shown to reduce the toxicity of these mycotoxins by approximately 100-fold (Kimura et al. 2007). Also upregulated in the daflo mutant were three genes related to efflux pumps or transporters. In comparison, only 56 predicted genes and two sequences with only EST support outside the deleted genomic region were downregulated in daf10 compared with the wild-type PH-1. Of these, $24(43 \%)$ had a predicted function. Further analysis revealed that both up- and downregulated genes in the daf10 mutant were located on each of the four $F$. graminearum chromosomes and no obvious skewed distribution patterns were evident.

\section{Characterization of the genes lost from daf10.}

The OmniMapFree software (J. Antoniw, unpublished) was used to explore in detail the genetic features and genes which are predicted to reside within the deleted region of chromosome 1 in daf10. The gene density in the deleted region was relatively uniform and was similar to the rest of chromosome 1 (Fig. 4A). However in the wild-type strain, this chromosome segment had a region with a very high frequency of meiotic recombination, and a second region with a more modest recombination frequency (Fig. 4B). The crossover event in FGSG_11677 that resulted in the daf10 deletion occurred in a region with a higher than average rate of meiotic recombination. Next, we explored whether this region contained any homologues of genes predicted to be essential for life in fungi (Nierman et al. 2005). None were found to be present. Then, we explored whether the region contained any homologues of previously characterized pathogenicity and virulence genes in other pathogenic species. This was done by BLASTP analysis using the entire contents of version 3.1 of the Pathogen-Host Interactions database (PHIbase) (Winnenburg et al. 2008). Four PHI-base genes with homologues in the daf10 deleted region of chromosome 1 with BLASTP $e$ values of less than e-100 (Table 6) were identified. An additional 20 PHI-base homologues with a verified role in pathogenicity or virulence with $e$ values between e-6 and e-99 were identified in this region. When the PHI-base proteins were queried against the whole $F$. graminearum genome, the top hit resided in the deleted region for only two of the PHI-base proteins (Table 6 , indicated in bold).

The functional categorization of the predicted proteins from the $F$. graminearum genome and of the daf10-deleted genes was downloaded from the MIPS Functional Catalogue Database (FunCat) version 2.0 (Ruepp et al. 2004). Approximately 50\% of the predicted proteins from the whole $\mathrm{PH}-1$ genome are unclassified. Interestingly, approximately $75 \%$ of the genes deleted from daf10 are unclassified. There were also several categories not represented among the deleted genes, including "cell cycle and DNA processing," "transcription," "cell fate," and "biogenesis of cellular components" (Fig. 5).

\section{Further characterization}

of the in planta phenotype of mutant daf10.

The absence of DON mycotoxin in the grain harvested from the daflo mutant-inoculated wheat ears indicated that a 
reevaluation of the ear infection phenotype was appropriate. For this analysis, flowering ears were point and spray inoculated with conidia from either wild-type $\mathrm{PH}-1$, daf10, or the tri5 mutant (in the PH-1 background) which is unable to produce DON mycotoxin either in planta or in vitro (Cuzick et al. 2008). The PH-1 strain caused severe ear bleaching, whereas both daf10 and tri5 infections caused the formation of eye-shaped lesions (Fig. 1B). However, overall, the daf10 mutant was more pathogenic than the tri5 mutant (Fig. 1B and C). Detailed analysis of the infected spikelets indicated that the glume tissue surrounding the daf10 eye-shaped lesions exhibited some bleaching as well as considerable aerial mycelium development. Also, the rachis tissue adjacent to the daf10-infected spikelets turned brown whereas, in the tri5 mutant-infected ears, the rachis remained green (Fig. 1C).

The phenotype associated with the daflo mutant was also compared with that of the previously generated single-genedeletion tril mutant (McCormick et al. 2004) on Arabidopsis floral tissue. On Arabidopsis, the infections of the daf10 and tril mutants were indistinguishable from each other and from the wild type (Fig. 6).

\section{The in vitro characteristics of mutant daf10.}

The growth and development of daflo was investigated and compared with the wild-type $\mathrm{PH}-1$ strain because of the large gene loss identified. First, fungal growth rates measured as colony diameters were compared on minimal medium, xylan medium, and potato dextrose broth (PDB) agar plates. Linear regression analysis showed that the wild-type strain PH-1 grew slightly faster $\left(1 \mathrm{~mm} \mathrm{day}^{-1}\right)$ than the daflo mutant on minimal medium (SNA) (Table 7). However, the difference was not significant at the $1 \%$ least significant difference (LSD) level. No significant differences were found for fungal growth rates on xylan or PDB medium. Next, we tested the ability to form perithecia, macroconidia, and ascospores. Perithecial formation in the daflo mutant and $\mathrm{PH}-1$

Table 6. Pathogen-Host Interactions database (PHI-base) homologues lost from daf10

\begin{tabular}{|c|c|c|c|c|c|c|c|c|}
\hline Locus $^{w}$ & $\begin{array}{l}\text { No. of } \\
\mathbf{a a}^{\mathrm{x}}\end{array}$ & MIPS annotation & $e$ Value & $\begin{array}{l}\text { PHI- } \\
\text { base }^{y}\end{array}$ & Gene name & Species & PHI-base annotation & Mutant $^{\mathrm{z}}$ \\
\hline 00006 & 297 & Related to gegh 16 protein & 2.74E-60 & PHI:257 & GAS2 & $\begin{array}{l}\text { Magnaporthe } \\
\text { grisea }\end{array}$ & Appressorial penetration & RV \\
\hline 00007 & 460 & $\begin{array}{l}\text { Related to } O \text {-methylsterig- } \\
\text { matocystin oxidoreductase }\end{array}$ & $1.24 \mathrm{E}-06$ & PHI:438 & $\begin{array}{l}B c B O T 1 \\
(C N D 5)\end{array}$ & Botrytis cinerea & $\begin{array}{l}\text { Cytochrome } \mathrm{P} 450 \\
\text { monooxygenase }\end{array}$ & RV \\
\hline 00012 & 519 & $\begin{array}{l}\text { Related to benzoate } 4 \text {-monooxy- } \\
\text { genase cytochrome } \mathrm{P} 450\end{array}$ & $6.10 \mathrm{E}-30$ & PHI:438 & $\begin{array}{l}B c B O T 1 \\
(C N D 5)\end{array}$ & B. cinerea & $\begin{array}{l}\text { Cytochrome } \mathrm{P} 450 \\
\text { monooxygenase }\end{array}$ & RV \\
\hline 00026 & 406 & $\begin{array}{l}\text { Related to monocarboxylate } \\
\text { transporter } 2\end{array}$ & $1.21 \mathrm{E}-53$ & PHI:812 & $M G G \_10702$ & M. grisea & Hypothetical protein & RV \\
\hline 00028 & 276 & $\begin{array}{l}\text { Probable metalloprotease } \\
\text { MEP1 }\end{array}$ & $1.40 \mathrm{E}-66$ & PHI:479 & MEP1 & $\begin{array}{l}\text { Coccidioides } \\
\text { posadasii }\end{array}$ & Metalloproteinase & $\mathbf{R V}$ \\
\hline 11654 & 738 & $\begin{array}{l}\text { Related to nitrate assimilation } \\
\text { regulatory protein }\end{array}$ & $2.51 \mathrm{E}-06$ & PHI:169 & CLTA1 & $\begin{array}{l}\text { Colletotrichum } \\
\text { lindemuthianum }\end{array}$ & Transcription factor & Loss \\
\hline 00036 & 1,599 & $\begin{array}{l}\text { Probable fatty acid synthase, } \\
\alpha \text { subunit }\end{array}$ & 0 & PHI:96 & $F A S 2$ & Candida albicans & Fatty acid synthetase & Loss \\
\hline 11655 & 409 & Related to cytochrome P450 & $2.75 \mathrm{E}-22$ & PHI:438 & $\begin{array}{l}\text { BcBOT1 } \\
(C N D 5)\end{array}$ & B. cinerea & $\begin{array}{l}\text { Cytochrome } \mathrm{P} 450 \\
\text { monooxygenase }\end{array}$ & RV \\
\hline 11656 & 2,061 & $\begin{array}{l}\text { Related to FAS1-fatty-acyl-coA } \\
\text { synthase, } \beta \text { chain }\end{array}$ & 0 & PHI:97 & $T O X C$ & $\begin{array}{l}\text { Cochliobolus } \\
\text { carbonum }\end{array}$ & Fatty acid synthetase & RV \\
\hline 11657 & 741 & Conserved hypothetical protein & $1.69 \mathrm{E}-10$ & PHI:52 & NUT1 & M. grisea & $\begin{array}{l}\text { Global regulation of } \\
\text { nitrogen utilization }\end{array}$ & RV \\
\hline 11659 & 4,469 & Nonribosomal peptide synthetase & 0 & PHI:12 & HTS1 & $\begin{array}{l}\text { Cochliobolus } \\
\text { carbonum }\end{array}$ & Cyclic peptide synthase & Loss \\
\hline 11660 & 906 & $\begin{array}{l}\text { NPS8 related to nonribosomal } \\
\text { peptide synthetase }\end{array}$ & $1.55 \mathrm{E}-109$ & PHI: 160 & $A M T$ & Alternaria alternata & AM toxin synthase & Loss \\
\hline 00046 & 1,446 & $\begin{array}{l}\text { Related to multidrug resistance } \\
\text { protein }\end{array}$ & $3.20 \mathrm{E}-65$ & PHI:267 & $M L T 1$ & Candida albicans & $\mathrm{ABC}$ transporter & RV \\
\hline 00049 & 383 & $\begin{array}{l}\text { Related to branched-chain amino } \\
\text { acid aminotransferase }\end{array}$ & $2.18 \mathrm{E}-81$ & PHI: 157 & TOXF & $\begin{array}{l}\text { Cochliobolus } \\
\text { carbonum }\end{array}$ & $\begin{array}{l}\text { Branched-chain-amino- } \\
\text { acid aminotransferase }\end{array}$ & Loss \\
\hline 00053 & 382 & $\begin{array}{l}\text { Probable AAD14 - strong simi- } \\
\text { larity to aryl-alcohol reductase }\end{array}$ & $5.39 \mathrm{E}-28$ & PHI:419 & $\mathrm{CSH} 1$ & Candida albicans & Cell surface protein & RV \\
\hline 00054 & 310 & Conserved hypothetical protein & $1.41 \mathrm{E}-08$ & PHI:784 & $M G G \_00056$ & M. grisea & Unknown & RV \\
\hline 11662 & 517 & Related to L-fucose permease & 7.31E-17 & PHI:441 & $B T P 1$ & B. cinerea & $\begin{array}{l}\text { G-protein coupled } \\
\text { receptor }\end{array}$ & RV \\
\hline 00078 & 328 & Related to aldo/keto reductase & $5.05 \mathrm{E}-26$ & PHI:419 & CSH1 & Candida albicans & Cell surface protein & RV \\
\hline 00081 & 691 & Conserved hypothetical protein & $3.87 \mathrm{E}-07$ & PHI:169 & CLTA1 & $\begin{array}{l}\text { Colletotrichum } \\
\text { lindemuthianum }\end{array}$ & Transcription factor & Loss \\
\hline 11670 & 126 & Conserved hypothetical protein & 1.99E-15 & PHI:489 & $T R X 1$ & $\begin{array}{r}\text { Cryptococcus } \\
\text { neoformans }\end{array}$ & Thioredoxin & $\mathbf{R V}$ \\
\hline 11671 & 842 & Related to $\beta$-glucosidase & $3.49 \mathrm{E}-38$ & PHI:24 & Avenacinase & $\begin{array}{l}\text { Gaeumannomyces } \\
\text { graminis }\end{array}$ & Avenacinase & Loss \\
\hline 00095 & 448 & $\begin{array}{l}\text { Related to tetracycline efflux } \\
\text { protein (otrb) }\end{array}$ & $2.14 \mathrm{E}-28$ & PHI:60 & TOXA & $\begin{array}{l}\text { Cochliobolus } \\
\text { carbonum }\end{array}$ & Toxin pump & Lethal \\
\hline 00101 & 335 & $\begin{array}{l}\text { Related to integral membrane } \\
\text { protein }\end{array}$ & $4.76 \mathrm{E}-19$ & PHI:404 & PTH11 & M. grisea & Membrane protein & RV \\
\hline 11677 & 752 & Conserved hypothetical protein & $1.91 \mathrm{E}-78$ & PHI:672 & CAS1 & $\begin{array}{c}\text { Cryptococcus } \\
\text { neoformans }\end{array}$ & $\begin{array}{l}\text { Capsule polysaccharide } \\
\text { biosynthesis }\end{array}$ & IV \\
\hline
\end{tabular}

${ }^{\mathrm{v}}$ If the FG locus was the top hit in a reciprocal BLASTP of the PHI-base entry against the Fusarium graminearum genome, the entry is printed in bold

${ }^{\mathrm{w}}$ F. graminearum locus ID (FG3 assembly genecalls FGSG_).

${ }^{x}$ Number of amino acids.

y Accession number of top hits in PHI-base by BLASTP.

${ }^{\mathrm{z}}$ Mutant defect: RV = reduced virulence, Loss $=$ loss of pathogenicity, and IV = Increased virulence (hypervirulence). 
was induced on carrot agar plates as described (Urban et al. 2003). Both the daflO mutant and the wild-type strain PH-1 produced black perithecia containing viable and normalsized ascospores within 2 weeks (Fig. 1D). Macroconidiospore formation and morphology of the daflo mutant strain was similar to the wild type (Fig. 1D, panel 2 and 5). The germination of macroconidiospores was assessed by pipetting spores of daflo and the wild-type in SNA agarose medium on microscope slides and then incubating for $12 \mathrm{~h}$ at $22^{\circ} \mathrm{C}$. No significant difference in germination rates between PH-1 and the daflo mutant was detected in four replicate experiments (means of $0.97 \pm 0.05$ and $0.96 \pm 0.01$, respectively). In summary, the daf10 mutant showed no significant defects in growth rates, perithecial formation, spore formation, and germination.

\section{DISCUSSION}

This study used a forward genetics approach and identified eight $F$. graminearum transformants with significantly reduced pathogenicity on wheat ears and roots. The transformant daf10, which appeared initially to harbor a single plasmid insertion event, was selected for detailed characterization. These analyses revealed the presence of a highly complex genomic alteration which led to the loss of 146 predicted genes from the end of chromosome 1 of daf10. In vitro, the mutant

Table 7. Comparison of growth rates of the daf10 mutant and wild-type strain in minimal medium (synthetic nutrient-poor agar.[SNA]) and two complete media (xylan and potato dextrose broth [PDB])

\begin{tabular}{lccc}
\hline & \multicolumn{3}{c}{ Growth on culture medium $\left(\mathbf{m m ~ d a y}^{\mathbf{- 1}}\right)^{\mathbf{z}}$} \\
\cline { 2 - 4 } Strain & SNA & Xylan & PDB \\
\hline daf-10 mutant & 17.35 & 18.20 & 17.85 \\
PH-1 & 18.43 & 17.50 & 17.63 \\
\hline
\end{tabular}

${ }^{\mathrm{z}}$ Mean growth rate measured as colony diameters $(n=4)$. Linear regression was applied to estimate the diameter growth rate for each colony. Analysis of variance revealed a marginally significant interaction between media and strains $(P=0.022, F$ test $)$. The standard error of difference of the mean for the strain - media interaction is 0.420 on 18 d.f. No significant differences for the means were found at the $1 \%$ least significant difference level, which was 1.209. daf10 grew normally and produced both sexual and asexual spores. On wheat ears, no trichothecene mycotoxin production was detected but the daflo infection phenotype was slightly more severe than that of the tri5 or the tril mutant whereas, on Arabidopsis floral tissue, both tril and daflo mutants exhibited wild-type pathogenicity. A microarray experiment done to explore gene expression under DON-inducing conditions revealed that the daf10 mutant also exhibited a considerably altered transcriptomic profile, involving both the increase and decrease in abundance of transcripts arising from genes located in other genomic regions.

The plasmid used to generate daf10, pHA1.3, was created for high-efficiency transformation of Colletotrichum lindemuthianum (Redman and Rodriguez 1994). This plasmid, originally recovered from an $F$. oxysporum transformant using the plasmid pFOLT4R4, contains Fusarium telomeric DNA as a result of an in vivo modification (Powell and Kistler 1990). A derivative of pFOLT4R4 which also retained this telomeric DNA (pLD) had previously been used to transform Nectria haematococca (anamorph: F. solani) and many of the resulting transformants were noted in pulsed-field gel electrophoresis analysis to have been subjected to large chromosomal deletions, up to 2 MB in some cases (Kistler and Benny 1992). The plasmid was originally chosen for mutagenesis because of the higher recovery rate of transformants, which appeared to be stable in initial tests of successive transfers.

By using the OmniMapFree software which links genome sequence information directly to the genetic map, we were able to explore the genome location surrounding the plasmid insertion that had occurred in the predicted gene FGSG_11677. This gene is in a genomic region that exhibits a higher than average level of meiotic recombination in a cross between strains PH-1 and a second American strain, MN00-620 (Gale et al. 2005), and is in a region of high single nucleotide polymorphism (SNP) occurrence (Cuomo et al. 2007). Double-strand breaks are created during meiotic recombination (Cao et al. 1990) and, in Saccharomyces cerevisiae, these breaks have been demonstrated to occur at specific chromosomal hotspots (Gerton et al. 2000).

The published, sequenced genome for the $F$. graminearum PH-1 lacks all eight telomeric regions. Therefore, although the predicted gene loss in the daf10 mutant is currently 146 genes,

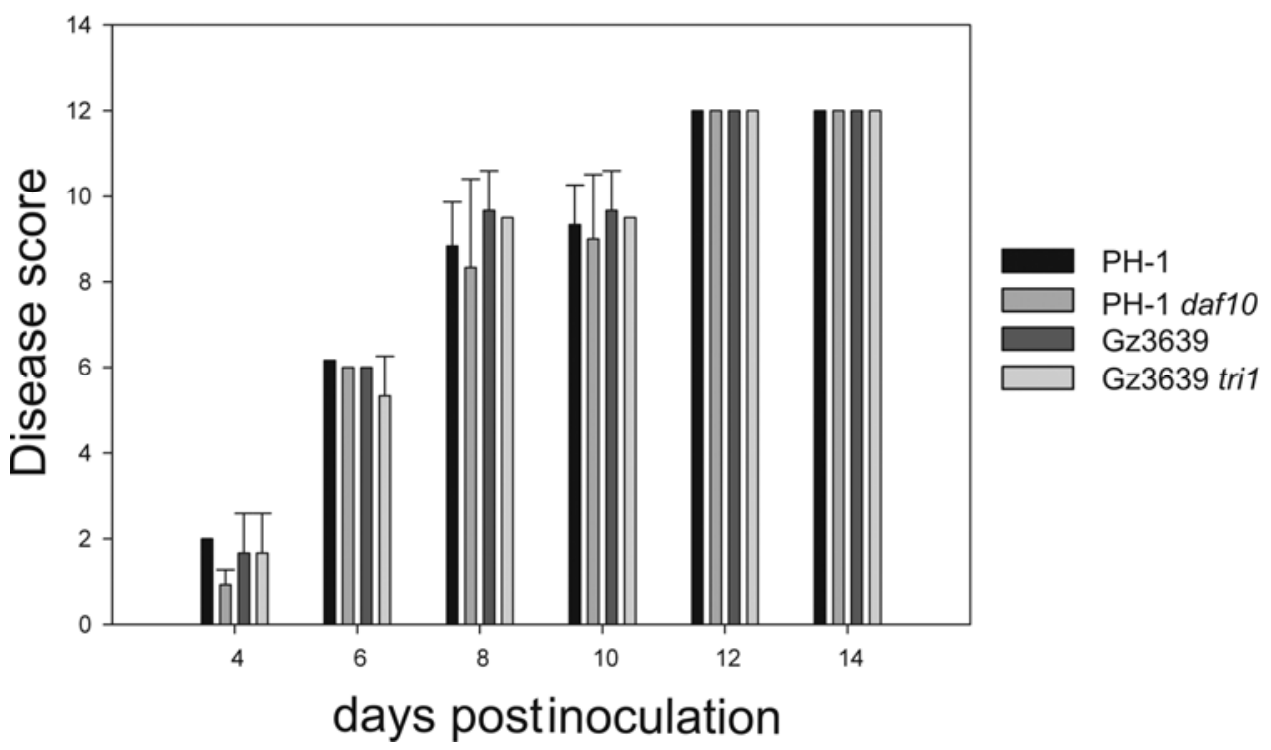

Fig. 6. Development of Fusarium graminearum infection on Arabidopsis ecotype Landsberg erecta floral tissue by the daf10 and tril mutants and the respective wild-type strains. Disease scores for the flowers and new siliques were assessed separately and then combined. Error bars indicate standard deviation $(n=12)$.

Vol. 23, No. 8, 2010 / 1091 
this number may rise once the full genomic sequence becomes available. The wild-type growth characteristics of daflo and its ability to grow vegetatively and to produce both sexual and asexual spores indicates either that none of the deleted genes have significant roles in Fusarium cell development or, alternatively, that their absence can be compensated for by genes residing in other parts of the genome. Our detailed bioinformatics analyses of the deleted region tends to indicate that the former view is the more likely explanation for the viability of the daf10 mutant because no genes "essential for life" were predicted to reside within this region. Also, no genes were predicted within four key gene ontology categories; namely, "cell cycle and DNA processing," "transcription," "cell fate," and "biogenesis of cellular components". Double-stranded breaks are normally highly deleterious, and organisms contain pathways to specifically suppress these events (Lee and Myung $2009)$. The tolerance of $F$. graminearum to this deletion provides the first functional evidence that nonessential genes are clustered in the telomeric regions. These regions have higher apparent variability, as suggested by SNP analysis, and many are species specific (Cuomo et al. 2007).

The precise pathogenicity defects in the daf10 mutant are difficult to predict beyond the loss of Tril. At least 20 genes were found to have some level of homology with known pathogenicity and virulence genes in other plant- or animalinfecting fungi. Alternatively, the defect may be conferred by one or more of the numerous unannotated genes. In $F$. graminearum, 23 genes have been shown thus far, through gene deletion or gene disruption experiments, to contribute to pathogenicity or virulence on wheat ears (Baldwin et al. 2006; Winnenburg et al. 2008). Interestingly, all these genes reside within regions of the genome which have either low or no recombination (Cuomo et al. 2007; Beacham et al. 2009; J. Antoniw, A. M. Beacham, M. Urban, and K. E. HammondKosack, unpublished), whereas the deleted genomic region in the daf10 mutant exhibits either a high or a moderate level of recombination. Although others have suggested that genes which reside within the subtelomeric regions of $F$. graminearum play a role in pathogenicity due to the observation that there is a preferential enrichment of in planta expressed genes in these genomic regions (Cuomo et al. 2007), this is the first direct evidence for such a role. The wheat seedling root assay results also indicate that a gene residing in this subtelomeric region also contributes to root colonization and pathogenesis, whereas the Arabidopsis floral inoculation results suggest that none of the genes residing within the deleted chromosomal region contribute to virulence toward this dicotyledonous host species, unless the simultaneous and balanced loss of both positive and negative regulators of pathogenicity has occurred in the daflo mutant.

The macroscopic daf10 disease phenotype on wheat ears was an unexpected result of this mutant. Although the number of colonized spikelets following point inoculation was minimal-typically, only those inoculated and their immediate neighbors exhibited disease symptoms-the glumes of each spikelet were not fully bleached. Instead, an eye-shaped lesion formed which was surrounded by limited glume bleaching and browning of the neighboring rachis tissue whereas, when the tri5 $F$. graminearum mutant in the $\mathrm{PH}-1$ genetic background infected the identical susceptible wheat genotype, only a dark border developed at the edge of the infection, and an eyeshaped lesion without bleaching of the surrounding glumes or browning of the rachis occurred (Fig. 1B and C). These contrasting in planta results indicate that, in the absence of DON accumulation, the daflo mutant disease phenotype is greater than that of the tri5 mutant (Cuzick et al. 2008). This would suggest that the product from another gene residing within the deleted chromosomal region is directly or indirectly responsible for limiting growth (or contributing to growth) in wheat ears. Alternatively, DON production may just be very low in the daf10-infected spikelets and, although able to induce eyeshaped lesion formation on the glumes accompanied by some glume bleaching, this infection does not lead to DON accumulation at significant levels in the developing grain.

The TRIl gene had been deleted from daflo. This gene, which codes for a cytochrome P450 monooxygenase, has previously been demonstrated to be essential for DON biosynthesis during in vitro growth of $F$. graminearum; however, the effects of this gene deletion on pathogenicity had not been reported (McCormick et al. 2004). Therefore, we compared the pathogenicity of this tril mutant in the Gz3639 genetic background with the daflo mutant on both wheat ears and Arabidopsis floral tissue. The later pathosystem was included because a previous study had reported that DON production does not contribute to $F$. graminearum pathogenicity of Arabidopsis (Cuzick et al. 2008). The tril mutant, like daf10, exhibited highly reduced pathogenicity on wheat ears and caused the formation of eye-shaped lesions. However, there were some subtle differences in the phenotypes of the daflo and tril mutants on wheat ears, with the daf10 mutant showing slightly more severe symptoms (Supplementary Fig. 4). It must be noted that the different parental backgrounds of these two mutants cannot be absolutely eliminated as the cause of these phenotypic differences. Both daflo and tril mutants caused wild-type infections on Arabidopsis buds, flowers, siliques, and upper stem tissue. Mutations in the TRII gene are known to cause the accumulation of calonectrin and 3-decalonectrin in F. graminearum (McCormick et al. 2004). Arabidopsis has been shown to be highly sensitive to these two compounds, with 3-calonectrin (50\% effective dose $7.6 \pm 1.4 \mu \mathrm{M})$ only slightly less toxic than DON $(3.8 \pm$ $3.0 \mu \mathrm{M})$ (Desjardins et al. 2007). The probable accumulation of calonectrin derivatives in the daf10 mutant would explain the wild-type pathogenicity effect on Arabidopsis and the reduced pathogenicity on wheat.

A recent report by Gardiner and associates (2009) used the Fusarium GeneChip to do a global analysis of fungal gene expression after 4 days under DON-noninducing and DONinducing conditions generated by amine compounds in culture (glutamine versus agmatine, respectively). The survey identified many genes which were differentially regulated under these conditions. One of the genes highly induced under their DONinducing conditions, namely FGSG_00007, which is on the lost arm of the chromosome in daf10, was selected for gene disruption. This mutation resulted in increased DON production (14fold) and increased aggressiveness toward wheat ears manifested as a greater rate of spread from spikelet to spikelet. The FGSG_00007 locus is predicted to encode a putative cytochrome P450 monooxygenase. In this study, the Fusarium GeneChip analysis were done after 7 days of growth under DON-inducing conditions and FGSG 00007 was not found to be differentially expressed. Gardiner and associates (2009) hypothesized that the product of FGSG_00007 may be involved in the negative regulation of DON biosynthesis. Thus, the dafl0 mutant originally selected on the phenotype of reduced aggressiveness toward wheat ears and low or no DON mycotoxin accumulation combines the loss of this negative regulator with the loss of an essential step in DON biosynthesis. This probably explains why subtle differences were consistently observed between the tril mutant and daflo mutant phenotypes, which could possibly be the result of an increased accumulation of calonectrin derivatives. An increased amount of these compounds may explain the increased virulence on wheat glumes of daf10. In addition, the loss of FGSG_00007 
resulted in increased production of other secondary metabolites (Gardiner et al. 2009), which may also render daf10 more virulent than the tril mutant. The FGSG_00007 mutant exhibits moderately increased virulence when point inoculated into cv. Bobwhite wheat ears compared with the parental wild-type strain CS3005 (G. Canning, Rothamsted Research, unpublished). Once the FGSG_00007 gene loss is available in the same parental background as the daflo mutant (namely, strain $\mathrm{PH}-1$ ), these biological and possible biochemical differences can be fully examined.

The microarray analysis of the daflo mutant under DONinducing conditions in vitro revealed that many additional genes located across the four $F$. graminearum chromosomes were specifically either up- or downregulated compared with the wild-type strain. Overall, considerably more gene transcripts were detected in increased abundance in the daf10 mutant (93 increased versus 58 decreased), suggesting that some genomewide positive transcriptional compensation was required to counter the presence of this sizeable genome deletion, which contains at least 146 genes. However, the global changes observed for the daf10 mutant were less than when single-genedeletion strains lacking either the transcription factors TRI6 or TRI10 were explored under the same DON-inducing conditions (Seong et al. 2009).

The analysis of the daf10 mutant clearly indicates how invaluable the emerging new tools and resources for $F$. graminearum are to the detailed characterization of mutants which resulted from a complex integration event. This analysis was only possible because of the availability of full genomic sequence information linked to a genetic map as well as a near-full genome microarray. The technique of random plasmid insertion combined with a forward genetic screen remains a very valuable approach to the discovery of novel pathogenicity and virulence genes. However, a proportion of the recovered mutants typically have multiple copy insertion events which makes the downstream analysis to recover the gene conferring the phenotype of interest difficult and time consuming. The analysis of multi-insertion mutants either singly or by pooling, via a combined microarray and high-throughput sequencing study, would be a rapid and informative way to distinguish between clean and "multicopy" insertion events, which could easily then be investigated by targeted single-gene-deletion experiments, from those which have led to either minor or more major genome rearrangements that would be more difficult to characterize further.

\section{MATERIALS AND METHODS}

\section{Strains and growth conditions.}

The strain Gz3639 was obtained from the United States Department of Agriculture stock culture collection (NRRL29169) whereas strain Gz3639 tril was obtained from the Fungal Genetics Stock Center Strains (FGSC 9501). F. graminearum PH-1 (FGSC 9075) was isolated from infected wheat in Michigan (Trail and Common 2000). Both Gz363 and PH-1 belong to genetic lineage group 7 (O'Donnell et al. 2000) and a whole-genome sequence is available (Cuomo et al. 2007). Both the wild-type and transformed strains were maintained as soil stocks at $-20^{\circ} \mathrm{C}$. All isolates were routinely cultured on SNA plates containing $0.1 \% \quad \mathrm{KH}_{2} \mathrm{PO}_{4}, 0.1 \%$ $\mathrm{KNO}_{3}, 0.1 \% \mathrm{MgSO}_{4} \times 7 \mathrm{H}_{2} \mathrm{O}, 0.05 \% \mathrm{KCl}, 0.02 \%$ glucose $0.02 \%$ saccharose, and 2\% Bacto Agar (Becton, Dickenson and Company, Sparks, MD, U.S.A. ) at $22^{\circ} \mathrm{C}$ under continuous white and blue fluorescent lights. Macroconidia for plant inoculation experiments were harvested from 10-day-old SNA agar plates. Perithecia production was induced on carrot agar (Trail et al. 2003).
Vectors for transformation of $\boldsymbol{F}$. graminearum.

Plasmid pHA1.3 was constructed with the hygromycin B phosphotransferase gene ( $h p h$ ) linked to the Aspergillus parasiticus trpC promoter and terminator sequences. In addition, this plasmid has a telomeric region from $F$. oxysporum inserted downstream of the $\operatorname{trp} C$ terminator (Redman and Rodriguez 1994).

\section{Fungal transformation.}

Transformations were done on germinated conidia using a previously published protocol (Proctor et al. 1995) with the following modifications. Approximately $0.3 \mathrm{~g}$ of a soil stock was used to inoculate carboxymethylcellulose (CMC) medium and incubated for $72 \mathrm{~h}$ at $25^{\circ} \mathrm{C}$ at $250 \mathrm{rpm}$. Conidia were harvested by centrifugation and germinated in YEPD broth $(0.3 \%$ yeast extract, $1 \%$ bactopeptone, and $2 \% \mathrm{D}$-glucose) for 12 to $14 \mathrm{~h}$ at room temperature at $175 \mathrm{rpm}$. Isolation of protoplasts occurred in driselase at $25 \mathrm{mg} / \mathrm{ml}$, chitinase (Sigma-Aldrich, St. Louis) at $0.05 \mathrm{mg} / \mathrm{ml}$, and either mureinase (USB-Amersham Pharmacia Biotech Inc., Piscataway, NJ, U.S.A.) at 0.5 $\mathrm{mg} / \mathrm{ml}$ or lysing enzyme (Sigma-Aldrich) at $5 \mathrm{mg} / \mathrm{ml}$ in a 1.2 $\mathrm{M} \mathrm{KCl}$ buffer. Protoplasts were collected by filtration through a 30- $\mu \mathrm{m}$ Nitex nylon membrane (Tetko Inc., Kansas City, MO, U.S.A.) and washed three times in STC buffer (1.2 M sorbitol, $10 \mathrm{mM}$ Tris- $\mathrm{HCl}$, and $50 \mathrm{mM} \mathrm{CaCl} 2, \mathrm{pH} \mathrm{8.0)}$. Transformation took place in the presence of $30 \%$ polyethylene glycol solution (10 mM Tris-HCl, $50 \mathrm{mM} \mathrm{CaCl}$, pH 8.0), STC buffer, and linearized plasmid. Protoplasts recovered on regeneration medium (RM) $(0.1 \%$ yeast extract, $0.1 \%$ casein enzyme hydrosylate, $0.8 \mathrm{M}$ sucrose, and $1 \%$ agarose) for $15 \mathrm{~h}$ and then were overlaid with $10 \mathrm{ml}$ of $\mathrm{RM}$ amended with hygromycin $\mathrm{B}$ (HygB) at $150 \mu \mathrm{g} / \mathrm{ml}$ (Calbiochem-Novabiochem Corp., San Diego, CA, U.S.A.). Putative transformants were selected within 4 to 7 days and retested for hygromycin resistance on V8 juice medium amended with $\mathrm{HygB}$ at $450 \mu \mathrm{g} / \mathrm{ml}$. $\mathrm{Hyg}^{\mathrm{r}}$ colonies were transferred to a $2 \%$ water agar medium and hyphal tipped to obtain genetically pure isolates.

\section{Infection assays on wheat plants.}

Preliminary screening of the population of Fusarium transformants was carried out on greenhouse-grown wheat cv. Norm. Seeds (four per 6-in. pot) were sown in high-porosity professional planting mix (Michigan Peat Company, Houston). Plants were fertilized weekly, starting 2 weeks after germination, until they reached the boot stage. Plants at early anthesis were selected for inoculation. Each $F$. graminearum transformant was grown in liquid carboxymethylcellulose medium to generate conidia as previously described (Guenther and Trail 2005). Plants were inoculated by placing $10 \mu \mathrm{l}$ of the spore suspension $\left(10^{5}\right.$ spores $\left./ \mathrm{ml}\right)$ within the floral chamber of a floret midway along the ear. Two plants were inoculated with each transformant and PH-1 was inoculated similarly on other ears as controls. The plants were placed in a misting chamber (misting frequency $10 \mathrm{~s}$ every $6 \mathrm{~min}$ ) for $72 \mathrm{~h}$ and then returned to standard greenhouse conditions. Wheat ears were assessed 8 to 13 days postinoculation for development of symptoms relative to that of PH-1. Symptoms observed were the extent of bleaching on the ears (two or more spikelets from the point of inoculation), deformation of the awn, and extent of seed set. If one of the two ears showed these symptoms, the strain was considered pathogenic.

For the secondary screen, seed of spring wheat cv. Bobwhite was sown in Levingtons C2 coarse potting compost. Seedlings were transplanted singly into $10-\mathrm{cm}$ pots and grown for an additional 2 months in a controlled environment growth room at $18^{\circ} \mathrm{C}$ during the 16 -h day and $16^{\circ} \mathrm{C}$ during the 8 -h night, at $50 \%$ relative humidity. Light was supplied by a mixture of metal hyalide and incandescent lamps to produce a fluence 
level of 207 microM at $86.2 \mathrm{~W} / \mathrm{msq}$ at the plant surface. Once the plants entered anthesis, individual attached ears were selected that bore two to five spikelets with extruded anthers. A small agar plug ( $2 \mathrm{~mm}$ in diameter) cut from the hyphal edge of each Fusarium insertional mutant growing on SNA media was then inserted into a single floret within the first full-sized spikelet down from the ear apex (Fig. 1). A second hyphal agar plug was inserted into an adjacent spikelet. The glumes of the two inoculated spikelets were marked with a waterproof pen. After inoculation, the entire plant was placed into a high-humidity chamber ( $>95 \%$ relative humidity) for the next 3 to 4 days. Light was excluded from the plants for $16 \mathrm{~h}$ postinoculation. The plants were then returned to the standard growth room conditions. Wheat ears were assessed at 4, 8, 12, 16, and 20 days postinoculation for disease. Disease symptoms were quantified by i) counting the total number of spikelets at and below the point of inoculation exhibiting bleaching symptoms, ii) noting the extent of brown streaking on the rachis segments below the point of inoculation, and iii) examining the ear region above the point of inoculation for bleaching. A minimum of six ears was inoculated for each insertional isolate and the same number of control PH-1 inoculated ears were included within each batch of inoculations.

The ability of each transformant with a reduced ability to cause ear blight symptoms to invade young wheat seedlings was explored by germinating Bobwhite wheat seed in a mixture of vermiculite and transformant hyphae. A 50-ml plastic container tube with drainage holes at the base (Steuwe and Sons, Inc, Oregon, OR, U.S.A.) was two-thirds filled with moist sterile vermiculite. Into the top surface was incorporated one-eighth of an entire 7-day-old SNA plate (diameter, $10 \mathrm{~cm}$ ) of a Fusarium isolate that had been chopped into small pieces $\left(5 \mathrm{~mm}^{3}\right)$. Three Bobwhite wheat seeds, from a stock known to give $100 \%$ germination, were placed onto the surface of the vermiculite/hyphal agar surface; then, a further $15 \mathrm{ml}$ of moist sterile vermiculite was added to completely cover the seeds. Seven identical containers were set up for each insertional Fusarium isolate tested. The finished containers were placed vertically in racks. Control containers were established with SNA agar only. To each container was added $10 \mathrm{ml}$ of water every second day for the 7 days and then daily thereafter. At 14 days after sowing, each container was scored nondestructively for seedling emergence. At 21 days after sowing, each container was disassembled, the vermiculite gently washed from the root system, and the roots scored for browning discoloration and physical appearance. In addition, the aerial parts of the emerged seedlings above the first leaf sheath were excised and the fresh weight determined. The experiment was repeated on two separate occasions.

Root tissue samples were taken at 21 days after inoculation from each insertional Fusarium isolate interaction. Conventional histochemical staining of fungal hyphae was performed using lactophenol-trypan blue and destaining with chloral hydrate (Keogh et al. 1980). Microscopic observations were made on a Carl Zeiss Axioskop 2 instrument under phase contrast.

\section{Infection assays on Arabidopsis plants.}

These assays were done by spray inoculation of conidia onto floral tissue of Arabidopsis thaliana accession Ler-0 using previously described methods (Cuzick et al. 2008). Twelve plants were sprayed with each Fusarium genotype or with water as a control.

\section{In vitro growth tests and microscopy.}

To measure fungal growth rates, mycelium plugs from 1week-old cultures on SNA minimal agar plates were transferred onto fresh agar plates using an 8-mm cork borer. Fungal growth was recorded as colony diameter in daily intervals over 5 days, which was prior to any colony reaching the edge of its dish. Germination of macrospores was assessed by embedding spores in SNA soft agarose on a microscope slide. SNA medium containing $0.7 \%$ low-melting-point agarose was cooled to $30^{\circ} \mathrm{C}$ and mixed with $5 \times 10^{4}$ spores $\mathrm{ml}^{-1}$. A $300-\mu \mathrm{l}$ aliquot of the spore mix was then used to coat a microscope slide with a thin layer of the agarose-spore medium. Coated slides were transferred to a high-humidity chamber at $22^{\circ} \mathrm{C}$ and germination was evaluated after $12 \mathrm{~h}$. A Zeiss Axiophot light microscope was used to examine spore morphology, size, and germination at higher magnifications. Perithecial formation on carrot agar plates was analyzed using a Leica MZFIII dissecting microscope.

\section{Competitive ELISA detection of DON and 15-acetyl DON.}

To induce trichothecene production, strains were grown in triplicate on liquid DON-inducing medium as previously described (McCormick et al. 2004). Samples from medium were recovered after 7 days of growth. Quantitative combined DON and 15-acetyl DON measurements were made using the commercial Veratox 5/5 kit (Neogen Corp., Lansing, MI, U.S.A.) and deploying a standard curve for DON ranging from 0.25 to $3.00 \mathrm{ppm}$. Optical densities at $650 \mathrm{~nm}$ values were measured after the addition of the stop solution to the multiwells. To ensure accuracy, each biological sample was quantified twice for combined DON and 15-acetyl DON levels.

\section{DNA gel blot analyses.}

Genomic DNA from various daf mutants and the PH-1 wildtype strain was extracted and digested with three different restriction enzymes which were predicted to cut either within the $h p h$ gene $(E c o \mathrm{RI})$ or within the inserted plasmid (SphI and $M l u \mathrm{I}$ ). The digested DNA was separated by size on large electrophoresis gels and blotted onto separate membranes (Hybond $\mathrm{N}^{+}$) using an alkali Southern blotting technique (Sambrook et al. 1989).

The DNA gel blot membranes were probed with a PCR-amplified fragment of the $h p h$ hygromycin resistance gene labeled with radioactive ${ }^{32} \mathrm{P}$. The DNA probe specifically hybridized with two fragments in the EcoRI-digested DNA gel blot, consistent with a single plasmid insertion. The EcoRI restriction enzyme is predicted to cut once within the $h p h$ gene, thereby generating two fragments.

\section{PCR, plasmid rescue, and sequencing.}

HotstarTaq (Qiagen, Hilden, Germany) was used for reactions with Fusarium genomic DNA. Reactions were done with volumes of $25 \mu \mathrm{l}$ in 200- $\mu$ l polypropylene PCR tubes with an Applied Biosystems (Warrington, U.K.) GeneAmp 9700 thermocycler. A Fermentas 1-kb Generuler was used to identify PCR product sizes in the subsequent agarose gel analyses.

A plasmid rescue technique described by Kuspa and Loomis (1992) was applied to isolating the flanking regions of plasmid pHA1.3 integrated into the genomic DNA of the daf10 mutant during protoplast.

Sequencing reactions were done with ABI Big Dye terminators V1.1 (Applied Biosystems). Sequencing reaction products were purified using an ethanol/sodium acetate method recommended by Applied Biosystems to remove unincorporated dye terminators. The extension products were sequenced on an ABI Prism 3730x1 DNA Analyser (University of Oxford, DNA Sequencing Facility, Oxford).

\section{Microarray analyses.}

Expression analysis was performed on DON-induced cultures grown as described above. RNA was extracted from three 
replicates of daf10 and two replicates of wild-type $\mathrm{PH}-1$ using the Trizol (Invitrogen, Carlsbad, CA, U.S.A.) cetyltrimethylammonium bromide-chloroform protocol reported by Hallen and associates (2007), followed by cleanup using RNeasy (Qiagen) following the manufacturer's directions. These RNAs were used to query Affymetrix Fusariuma520094 GeneChips (Güldener et al. 2006) following standard protocols (Affymetrix 2004). The hybridization signals were scanned with a GeneChip GCS 3000 Scanner (Affymetrix) and the cell intensity (CEL) files were obtained from GCOS 2.1 software (Affymetrix). CEL files were normalized in the Bioconductor package of $\mathrm{R}$, version 2.3.0rc (Gentleman et al. 2004, R Development Core Team 2006), using RMA, an expression measure that accounts for background correction, quantile normalization, and variation between arrays (Irizarry et al. 2003a,b). Comparisons between daf10 and the wild type were conducted using the Limma package of Bioconductor (Smyth 2005; Hallen and Trail 2008). Statistical significance was empirically determined by selecting the cutoff $P$ value lower than the smallest $P$ value found in any of the Affymetrix control probe sets, as recommended by Smyth (2005). Microarray data and CEL files are available at Plexdb as FG17.

\section{Other statistical analyses.}

The one-sample $t$ test was used to identify statistically significant differences between two populations. One-way analysis of variance (ANOVA) with blocking was used to identify LSD between more than two populations. The computer program Genstat, version 9.2 (VSN International, Oxford), was used for these statistical calculations. The Microsoft Excel computer program was used for calculating means, standard deviations, and $P$ values for the $\chi^{2}$ test.

A two-stage analysis was used to analyze the growth rates of fungal colonies. First, diameters of the colonies were plotted against time for each replicate dish and were found to increase linearly. Linear regression was applied to estimate the diameter growth rate (millimeters per day) for each colony. For the second stage of the analysis, ANOVA was used to consider the significance of differences between the treatment combinations (media-strains). Following the ANOVA, means were compared using the LSD at the $1 \%$ level of significance.

\section{ACKNOWLEDGMENTS}

We thank R. Loranger, A. Pandya, and Y. Letourneau for their assistance with the primary screening experiments; E. Mott, T. Farley, and W. Phillips for their assistance with the secondary screening experiments; and I. Pearman and J. Franklin for maintenance of controlled environment facilities at Rothamsted Research. All experiments at Rothamsted Research involving $F$. graminearum $\mathrm{PH}-1$, GZ3639, the daf mutants, the tri5 mutant, and the tril mutant were conducted in biological containment facilities under Food and Environment Research Agency license no. PHL 174E/5543. Rothamsted Research receives grant-aided support from the Biotechnology and Biological Sciences Research Council (BBSRC) of the United Kingdom. T. K. Baldwin was supported by a BBSRC studentship with Syngenta as the CASE partner. This material is based upon work supported in part by the United States Department of Agriculture, under agreement no. 59-0790-6-068 to F. Trail. This was a cooperative project with the U.S. Wheat \& Barley Scab Initiative. The research was also supported in part by a grant to F. Trail from Monsanto Company, St. Louis, and the Michigan Agricultural Experiment Station.

\section{LITERATURE CITED}

Affymetrix. 2004. GeneChip expression analysis. Affymetrix, Santa Clara, CA, U.S.A.

Alexander, N. J., McCormick, S. P., Larson, T. M., and Jurgenson, J. E. 2004. Expression of Tri15 in Fusarium sporotrichioides. Curr. Genet. 45:157-162.

Baldwin, T. K., Winnenburg, R., Urban, M., Rawlings, C., Koehler, J., and
Hammond-Kosack, K. E. 2006. The pathogen-host interactions database (PHI-base) provides insights into generic and novel themes of pathogenicity. Mol. Plant-Microbe Interact. 19:1451-1462.

Beacham, A. M., Antoniw, J., and Hammond-Kosack, K. E. 2009. A genomic fungal foray. Biologist 56:98-105.

Cao, L., Alani, E., and Kleckner, N. 1990. A pathway for generation and processing of double-strand breaks during meiotic recombination in Saccharomyces cerevisiae. Cell 61:1089-1101.

Cuomo, C. A., Güldener, U., Xu, J. R., Trail, F., Turgeon, B. G., Di Pietro, A., Walton, J. D., Ma, L. J., Baker, S. E., Rep, M., Adam, G., Antoniw, J., Baldwin, T., Calvo, S., Chang, Y. L., DeCaprio, D., Gale, L. R., Gnerre, S., Goswami, R. S., Hammond-Kosack, K., Harris, L. J., Hilburn, K., Kennell, J. C., Kroken, S., Magnuson, J. K., Mannhaupt, G., Mauceli, E., Mewes, H. W., Mitterbauer, R., Muehlbauer, G., Munsterkotter, M., Nelson, D., O’Donnell, K., Ouellet, T., Qi, W. H., Quesneville, H., Roncero, M. I. G., Seong, K. Y., Tetko, I. V., Urban, M., Waalwijk, C., Ward, T. J., Yao, J. Q., Birren, B. W., and Kistler, H. C. 2007. The Fusarium graminearum genome reveals a link between localized polymorphism and pathogen specialization. Science 317:1400-1402.

Cuzick, A., Urban, M., and Hammond-Kosack, K. 2008. Fusarium graminearum gene deletion mutants mapl and tri5 reveal similarities and differences in the pathogenicity requirements to cause disease on Arabidopsis and wheat floral tissue. New Phytol. 177:990-1000.

Desjardins, A. E., McCormick, S. P., and Appell, M. 2007. Structure-activity relationships of trichothecene toxins in an Arabidopsis thaliana leaf assay. J. Agric. Food Chem. 55:6487-6492.

Gale, L. R., Bryant, J. D., Calvo, S., Giese, H., Katan, T., O’Donnell, K., Suga, H., Taga, M., Usgaard, T. R., Ward, T. J., and Kistler, H. C. 2005. Chromosome complement of the fungal plant pathogen Fusarium graminearum based on genetic and physical mapping and cytological observations. Genetics 171:985-1001.

Gardiner, D. M., Kazan, K., and Manners, J. M. 2009. Novel genes of Fusarium graminearum that negatively regulate deoxynivalenol production and virulence. Mol. Plant-Microbe Interact. 22:1588-1600.

Gentleman, R. C., Carey, V. J., Bates, D. M., Bolstad, B., Dettling, M., Dudoit, S., Ellis, B., Gautier, L., Ge, Y. C., Gentry, J., Hornik, K., Hothorn, T., Huber, W., Iacus, S., Irizarry, R., Leisch, F., Li, C., Maechler, M., Rossini, A. J., Sawitzki, G., Smith, C., Smyth, G., Tierney, L., Yang, J. Y. H., and Zhang, J. H. 2004. Bioconductor: Open software development for computational biology and bioinformatics. Genome Biol. 5:R80.

Gerton, J. L., DeRisi, J., Shroff, R., Lichten, M., Brown, P. O., and Petes, T. D. 2000. Global mapping of meiotic recombination hotspots and coldspots in the yeast Saccharomyces cerevisiae. Proc. Natl. Acad. Sci. U.S.A. 97:11383-11390.

Güldener, U., Seong, K.-Y., Boddu, J., Cho, S., Trail, F., Xu, J.-R., Adam, G., Mewes, H.-W., Muehlbauer, G. J., and Kistler, H. C. 2006. Development of a Fusarium graminearum Affymetrix GeneChip for profiling fungal gene expression in vitro and in planta. Fungal Genet. Biol. 43:316-325

Guenther, J. C., and Trail, F. 2005. The development and differentiation of Gibberella zeae (anamorph: Fusarium graminearum) during colonization of wheat. Mycologia 97:229-237.

Hallen, H. E., and Trail, F. 2008. The L-type calcium ion channel Cch1 affects ascospore discharge and mycelial growth in the filamentous fungus Gibberella zeae (anamorph Fusarium graminearum). Eukaryot. Cell 7:415-424.

Hallen, H. E., Huebner, M., Shiu, S. H., Güldener, U., and Trail, F. 2007. Gene expression shifts during perithecium development in Gibberella zeae (anamorph Fusarium graminearum), with particular emphasis on ion transport proteins. Fungal Genet. Biol. 44:1146-1156.

Hou, Z. M., Xue, C. Y., Peng, Y. L., Katan, T., Kistler, H. C., and Xu, J. R. 2002. A mitogen-activated protein kinase gene (MGV1) in Fusarium graminearum is required for female fertility, heterokaryon formation, and plant infection. Mol. Plant-Microbe Interact. 15:1119-1127.

Irizarry, R. A., Bolstad, B. M., Collin, F., Cope, L. M., Hobbs, B., and Speed, T. P. 2003a. Summaries of Affymetrix GeneChip probe level data. Nucleic Acids Res. 31:e15.

Irizarry, R. A., Hobbs, B., Collin, F., Beazer-Barclay, Y. D., Antonellis, K. J., Scherf, U., and Speed, T. P. 2003b. Exploration, normalization, and summaries of high density oligonucleotide array probe level data. Biostatistics 4:249-264.

Jansen, C., von Wettstein, D., Schafer, W., Kogel, K. H., Felk, A., and Maier, F. J. 2005. Infection patterns in barley and wheat spikes inoculated with wild-type and trichodiene synthase gene disrupted Fusarium graminearum. Proc. Natl. Acad. Sci. U.S.A. 102:1689216897.

Keogh, R. C., Deverall, B. J., and McLeod, S. 1980. Comparison of histological and physiological responses to Phakopsora pachyrhizi in resistant and susceptible soybean. Trans. Br. Mycol. Soc. 74:329-333.

Kimura, M., Tokai, T., Takahashi-Ando, N., Ohsato, S., and Fujimura, M. 
2007. Molecular and genetic studies of Fusarium trichothecene biosynthesis: Pathways, genes, and evolution. Biosci. Biotechnol. Biochem. 71:2105-2123.

Kistler, H. C., and Benny, U. 1992. Autonomously replicating plasmids and chromosome rearrangement during transformation of Nectria hae matococca. Gene 117:81-89.

Kuspa, A., and Loomis, W. F. 1992. Tagging developmental genes in Dictyostelium by restriction enzyme-mediated integration of plasmid DNA. Genetics 89:8803-8807.

Lee, S. E., and Myung, K. 2009. Faithful after break-up: Suppression of chromosomal translocations. Cell. Mol. Life Sci. 66:3149-3160.

McCormick, S. P., Harris, L. J., Alexander, N. J., Ouellet, T., Saparno, A., Allard, S., and Desjardins, A. E. 2004. Tri1 in Fusarium graminearum encodes a P450 oxygenase. Appl. Environ. Microbiol. 70:2044-2051.

Nierman, W. C., Pain, A., Anderson, M. J., Wortman, J. R., Kim, H. S., Arroyo, J., Berriman, M., Abe, K., Archer, D. B., Bermejo, C., Bennett, J., Bowyer, P., Chen, D., Collins, M., Coulsen, R., Davies, R., Dyer, P. S., Farman, M., Fedorova, N., Feldblyum, T. V., Fischer, R., Fosker, N., Fraser, A., Garcia, J. L., Garcia, M. J., Goble, A., Goldman, G. H., Gomi, K., Griffith-Jones, S., Gwilliam, R., Haas, B., Haas, H., Harris, D., Horiuchi, H., Huang, J., Humphray, S., Jimenez, J., Keller, N., Khouri, H., Kitamoto, K., Kobayashi, T., Konzack, S., Kulkarni, R., Kumagai, T., Lafton, A., Latge, J. P., Li, W. X., Lord, A., Majoros, W. H., May, G. S. Miller, B. L., Mohamoud, Y., Molina, M., Monod, M., Mouyna, I., Mulligan, S., Murphy, L., O’Neil, S., Paulsen, I., Penalva, M. A., Pertea, M., Price, C., Pritchard, B. L., Quail, M. A., Rabbinowitsch, E., Rawlins, N., Rajandream, M. A., Reichard, U., Renauld, H., Robson, G. D., de Cordoba, S. R., Rodriguez-Pena, J. M., Ronning, C. M., Rutter, S., Salzberg, S. L., Sanchez, M., Sanchez-Ferrero, J. C., Saunders, D., Seeger, K., Squares, R., Squares, S., Takeuchi, M., Tekaia, F., Turner, G. de Aldana, C. R. V., Weidman, J., White, O., Woodward, J., Yu, J. H., Fraser, C., Galagan, J. E., Asai, K., Machida, M., Hall, N., Barrell, B., and Denning, D. W. 2005. Genomic sequence of the pathogenic and allergenic filamentous fungus Aspergillus fumigatus. Nature 438:1151-1156.

Ochiai, N., Tokai, T., Nishiuchi, T., Takahashi-Ando, N., Fujimura, M., and Kimura, M. 2007. Involvement of the osmosensor histidine kinase and osmotic stress-activated protein kinases in the regulation of secondary metabolism in Fusarium graminearum. Biochem. Biophys. Res. Commun. 363:639-644.

O’Donnell, K., Kistler, H. C., Tacke, B. K., and Casper, H. H. 2000. Gene genealogies reveal global phylogeographic structure and reproductive isolation among lineages of Fusarium graminearum, the fungus causing wheat scab. Proc. Natl. Acad. Sci. U.S.A. 97:7905-7910.

Parry, D. W., Jenkinson, P., and McLeod, L. 1995. Fusarium ear blight (scab) in small-grain cereals-a review. Plant Pathol. 44:207-238.

Powell, W. A., and Kistler, H. C. 1990. In vivo rearrangement of foreign DNA by Fusarium oxysporum produces linear self-replicating plasmids. J. Bacteriol. 172:3163-3171.

Proctor, R. H., Hohn, T. M., and McCormick, S. P. 1995. Reduced virulence of Gibberella zeae caused by disruption of a trichothecene toxin biosynthetic gene. Mol. Plant-Microbe Interact. 8:593-601.

Ramamoorthy, V., Zhao, X. H., Snyder, A. K., Xu, J. R., and Shah, D. M. 2007. Two mitogen-activated protein kinase signalling cascades mediate basal resistance to antifungal plant defensins in Fusarium graminearum. Cell. Microbiol. 9:1491-1506.

R Development Core Team. 2006. R: A Language and Environment for Statistical Computing. R Foundation for Statistical Computing, Vienna.

Redman, R. S., and Rodriguez, R. J. 1994. Factors affecting the efficient transformation of Colletotrichum species. Exp. Mycol. 18:230-246.

Ruepp, A., Zollner, A., Maier, D., Albermann, K., Hani, J., Mokrejs, M. Tetko, I., Güldener, U., Mannhaupt, G., Munsterkotter, M., and Mewes, H. W. 2004. The FunCat, a functional annotation scheme for systematic classification of proteins from whole genomes. Nucleic Acids Res. 32:5539-5545.

Sambrook, J., Fritsch, E., and Maniatis, T. 1989. Molecular Cloning: A Laboratory Manual. Cold Spring Harbor Laboratory Press, Plainview, NY, U.S.A.

Seong, K. Y., Pasquali, M., Zhou, X. Y., Song, J., Hilburn, K., McCormick, S., Dong, Y. H., Xu, J. R., and Kistler, H. C. 2009. Global gene regulation by Fusarium transcription factors Tri6 and Tri10 reveals adaptations for toxin biosynthesis. Mol. Microbiol. 72:354-367.

Smyth, G. K. 2005. Limma: Linear models for microarray data. In: Bioinformatica and Computational Biology Solutions Using $\mathrm{R}$ and Bioconductor. R. Gentleman, V. Carey, S. Dudoit, R. Irizarry, and W. Huber, eds. Springer, New York.

Trail, F. 2009. For blighted waves of grain: Fusarium graminearum in the postgenomics era. Plant Physiol. 149:103-110.

Trail, F., and Common, R. 2000. Perithecial development by Gibberella zeae: A light microscopy study. Mycologia 92:130-138.

Trail, F., Xu, J. R., San Miguel, P., Halgren, R. G., and Kistler, H. C. 2003. Analysis of expressed sequence tags from Gibberella zeae. (anamorph Fusarium graminearum). Fungal Genet. Biol. 38:187-197.

Turgeon, B. G., Garber, R. C., and Yoder, O. C. 1987. Development of a fungal transformation system based on selection of sequences with promoter activity. Mol. Cell. Biol. 7:3297-3305.

Urban, M., Mott, E., Farley, T., and Hammond-Kosack, K. 2003. The Fusarium graminearum MAPl gene is essential for pathogenicity and development of perithecia. Mol. Plant Pathol. 4:347-359.

Winnenburg, R., Urban, M., Beacham, A., Baldwin, T. K., Holland, S. Lindeberg, M., Hansen, H., Rawlings, C., Hammond-Kosack, K. E., and Kohler, J. 2008. PHI-base update: Additions to the pathogen-host interaction database. Nucleic Acids Res. 36:D572-D576.

\section{AUTHOR-RECOMMENDED INTERNET RESOURCES}

OmniMapFree software: www.omnimapfree.org

The Plant Expression database (PLEXdb): www.plexdb.org 